\title{
Recent Development of Benzotriazole-based Medicinal Drugs
}

\author{
Yu Ren, Ling Zhang, Cheng-He Zhou and Rong-Xia Geng* \\ Institute of Bioorganic \& Medicinal Chemistry, School of Chemistry and Chemical Engineering, Southwest University, Chongqing 400715, People's Republic of China
}

\begin{abstract}
The extensively clinical use of triazole-based medicinal drugs has been promoting increasing effort to develop new structural triazole derivatives. Benzotriazoles as fused aromatic nitrogen heterocycles of benzene ring with triazole exhibit wide potentialities in medicinal chemistry since some anticancer benzotriazole compounds like vorozole and 4,5,6,7-tetrabromo-1 $\mathrm{H}$-benzotriazole (TBB) were used in clinical therapy. The benzotriazole related investigations are becoming increasingly active. On the basis of authors' researches and other literature in recent five years, this work for the first time gave a comprehensive review on the latest and outstanding developments of benzotriazole compounds in medicinal chemistry, including as anticancer, antifungal, antibacterial, antitubercular, antiviral, antioxidative, antiparasitic, antioxidative agents and so on. Hopefully, this contribution will be helpful to develop benzotriazole-based drugs with high bioactivity and low toxicity.
\end{abstract}

Keywords: Benzotriazole; Anticancer; Antifungal; Antibacterial; Antitubercular; Antiviral; Antiparasitic; Antioxidative

\section{Introduction}

Azole heterocyclic compounds exhibit wide range of medicinal applications in the treatment of various types of diseases [1]. Especially, triazole derivatives as medicinal drugs have been playing important roles in medicinal chemistry [2-4], and a lot of triazole analogs including imidazole [5], thiazole [6], carbazole [7,8], oxazole [9] and benzimidazole $[10,11]$, etc. have also been found to be widely used in clinic. Benzotriazole is a fused aromatic nitrogen heterocycle of benzene ring with triazole, and its derivatives have been paid increasingly special attention due to their widely potential applications as medicinal drugs [12], corrosion inhibitors [13], man-made materials [14], supramolecular ligands [15], therefore large numbers of researches have already been focused on this attractive area. Notably, bioactive benzotriazole-based compounds are being deeply exploited all over the world to treat different kinds of puzzling diseases like cancers and the current researches of benzotriazole derivatives in medicinal chemistry have achieved great progress. Different from triazole, the fused benzene ring makes benzotriazole nucleus possess a larger conjugated system to form $\pi-\pi$ stacking interactions, and its three nitrogen atoms make it easy to form hydrogen bonds and coordination bonds, thereby benzotriazole derivatives are more ready to bind with a variety of enzymes and receptors in biological system via diverse non-covalent interactions, resulting in a broad spectrum of biological activities. Furthermore, benzotriazole compounds could bind with different metal ions to produce benzotriazole-containing metal complexes, which may possess the bioactivities of both benzotriazole derivatives themselves and supramolecular agents, thus possibly exerting double action mechanisms to overcome drug resistances [16]. For the above reasons, benzotriazole moiety has been commonly employed to construct innovative drug molecules [17]. Particularly, some anticancer benzotriazole derivatives such as vorozole and TBB have been in clinical use or trial. Recently, more and more benzotriazole derivatives with effective pharmacological properties, low toxicity, few side effects, little multi-drug resistance, good water solubility, promising bioavailability, diversity of drug administration as well as broad bioactive spectrum have been frequently discovered, which have shown large development value and potentiality as medicinal drugs [18]. In view of these, on the basis of authors' researches and other literature in recent five years, this work for the first time systematically reviewed the progress of benzotriazole compounds in medicinal chemistry, including as anticancer, antifungal, antibacterial, antitubercular, antiviral, antiparasitic, antioxidative, as well as other medicinal drugs, and some comments on structure-activity relationships are also discussed.

\section{Anticancer Benzotriazoles}

A variety of anticancer drugs such as alkylating agents, platinum complexes, porphyrin drugs and azole agents have been successfully developed and clinically used to treat various cancers [19]. However, most of the clinical anticancer drugs are often toxic to normal tissues, thus causing numerous side effects, which, in turn, limit the treatment efficacy (Figure 1). Long term effectiveness is also limited by dose-related cumulative cardiotoxicity as well as drug resistance [20,21]. Therefore, an increasing number of researches have been directing towards the design and development of new therapeutic agents for the treatment of cancers. Several benzotriazole derivatives have been found to possess potent anticancer activity, for example, the antineoplastic agent vorozole that is in clinical trial, and 4,5,6,7-tetrabromobenzotriazole (TBB) (compound 1a) is a commercial available anticancer drug with high selective inhibition against protein kinase CK2 [22]. The successful exploration of TBB stimulates the continuous effort towards the development of novel benzotriazole-based anticancer agents targeting various kinases or receptors. Moreover, an increasing number of new structural benzotriazole derivatives as well as benzotriazole-containing metal complexes have displayed considerable potentiality to overcome the diverse drawbacks of currently available clinical drugs [23].

The inhibition of kinases is one of the most important pathways to treat cancers attributing to the significant roles of kinases in cell multiplication [24]. The special structure of benzotriazole derivatives could readily bind with different kinases via multiple non-covalent forces such as hydrogen bonds, coordination, ion-dipole, cation- $\pi, \pi-\pi$ stacking, hydrophobic effect and van der Waals force, thus effectively inhibiting the activity of various kinases including protein kinases CK2 and CHK1, histone deacetylases and focal adhesion kinase and so on.

*Corresponding author: Rong-Xia Geng, School of Chemistry and Chemical Engineering, Southwest University, Chongqing 400715, People's Republic of China Tel: +86-23-68254967; Fax: +86-23-68254967; E-mail: mailto:geng0712@swu.edu.cn

Received June 24, 2014; Accepted August 18, 2014; Published August 20, 2014

Citation: Ren Y, Zhang L, Zhou CH, Geng RX (2014) Recent Development of Benzotriazole-based Medicinal Drugs. Med chem 4: 640-662. doi:10.4172/21610444.1000207

Copyright: (C) 2014 Ren Y, et al. This is an open-access article distributed under the terms of the Creative Commons Attribution License, which permits unrestricted use, distribution, and reproduction in any medium, provided the original author and source are credited. 
<smiles>[R]c1c(Br)c(Br)c2nnn([R])c2c1Br</smiles>

1a, $\mathrm{R}^{1}=\mathrm{Br}, \quad \mathrm{R}^{2}=\mathrm{H}$

1b, $\mathrm{R}^{1}=\mathrm{Br}, \quad \mathrm{R}^{2}=\left(\mathrm{CH}_{2}\right)_{3} \mathrm{OH}$

1c, $\mathrm{R}^{1}=\mathrm{CH}_{3}, \mathrm{R}^{2}=\left(\mathrm{CH}_{2}\right)_{3} \mathrm{NH}_{2}$<smiles>O=C(Nc1ccccc1N1CCNCC1)c1csc(N(n2nnc3ccccc32)n2nnc3ccccc32)n1</smiles><smiles>COc1cc(C(=O)On2nnc3ccccc32)cc(OC)c1OC</smiles><smiles>Fc1ccccc1CSc1nnc(Cn2nnc3ccccc32)o1</smiles><smiles>COc1ccc2cc(C(=O)NCCCn3nnc4ccccc43)ccc2c1</smiles><smiles>COc1ccc(/C=C(\C#N)n2nnc3ccccc32)cc1</smiles><smiles>[R][R6](=C)c1ccc2nnn(CC(OC(=O)c3ccccc3)C(=O)c3ccc([R])cc3)c2c1</smiles><smiles>CN(C)CCNC(=O)c1cccc2nc3ccccc3c(NCCn3nnc4ccccc43)c12</smiles><smiles>CC(=O)OC1[C@H](n2nnc3ccccc32)CC2C3CCC4CC(N(C)c5ccccc5)CCC4(C)C3CCC21C</smiles>

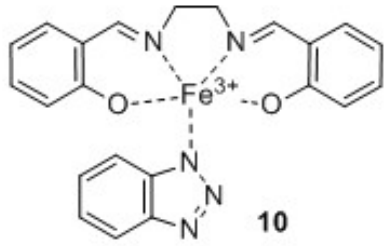<smiles></smiles><smiles>CC(c1ccccc1)n1nnc2ccccc21</smiles>

Figure 1: Anticancer Benzotriazoles.

Human protein kinase CK2 is a constitutively active protein kinase with an ever-expanding list of interacting partners and substrates and plays key regulatory roles in many cellular signaling events $[25,26]$. It could usually disrupt the growth and promote the cell death of several cancer cell lines. The tetrabromo substituted benzotriazole TBB (compound 1a) is a clinical CK2 inhibitor, which is significantly selective and more effective to inhibit protein kinase CK2 in comparison to other kinases, and it could bind with CK2 in a quite different manner from other inhibitors [27]. Researches revealed that its four bromine atoms in benzotriazole ring were essential requirement for the inhibitory activity [28]. Recently, several new TBB derivatives have been developed and employed to inhibit CK2 in various proteins with important metabolic functions $[29,30]$. For example, the introduction of a propanol moiety into TBB at 1-position (compound $1 \mathrm{~b}$ ) resulted in a better inhibition with half maximal inhibitory concentration $\left(\mathrm{IC}_{50}\right.$ value) of $0.32 \mu \mathrm{g} / \mathrm{mL}$ in comparison to the parental $\mathrm{TBB}\left(\mathrm{IC}_{50}=0.56 \mu \mathrm{g} / \mathrm{mL}\right)$. However, when the propanol fragment was changed into its 2-position, the inhibitory activity slightly decreased. The further evaluation of $\left[{ }^{14} \mathrm{C}\right]$ radioactivity in all the examined human organs showed that this compound could cross the blood/brain barrier, which made it a promising candidate for further modification as a potential therapeutic agent [31]. Recent literature has also reported that 5-methyl-TBB indeed interacted with CK2. In addition, the substitution of the bromine atom by a methyl group at 5-position and the introduction of a propylamine at 1-position (compound 1c) exhibited less inhibition $\left(\mathrm{IC}_{50}=0.98 \mu \mathrm{g} / \mathrm{mL}\right.$ ) than $\mathrm{TBB}$ [32]. The precise understanding of their mode of action within cells remains incomplete, and this new kind of TBB derivatives with great developing potentiality in anticancer field is worthy to be investigated in-depth [33].<smiles>[R]c1c(Br)c(Br)c2c(nnn2[R2])c1Br</smiles>
1a, $\mathrm{R}^{1}=\mathrm{Br}, \quad \mathrm{R}^{2}=\mathrm{H}$
1b, $\mathrm{R}^{1}=\mathrm{Br}, \quad \mathrm{R}^{2}=\left(\mathrm{CH}_{2}\right)_{3} \mathrm{OH}$
1c, $\mathrm{R}^{1}=\mathrm{CH}_{3}, \mathrm{R}^{2}=\left(\mathrm{CH}_{2}\right)_{3} \mathrm{NH}_{2}$

Human Cell Cycle Checkpoint Kinase Homologue 1 (CHK1) is a threonine protein kinase that arrests the cell cycle progression in response to the DNA damage induced by particular anticancer therapeutics. The inhibition of CHK1 could sensitize defective tumor cells to the cytotoxic effects of anticancer DNA-damaging agents and result in an expanded therapeutic opportunity. Benzotriazole substituted aminothiazole derivative 2 showed a mild inhibition against CHK1 $\left(\mathrm{IC}_{50}=110 \mathrm{nmol} / \mathrm{mL}\right.$ ) [34]. Its unsatisfactory activity is possibly caused by the weak ability to accept an H-bond from the Cys87 amide or weak interactions between the nitrogen atoms of benzotriazole and carbonyl groups of nearby protein. 
<smiles>O=C(Nc1ccccc1N1CCNCC1)c1csc(-n2nnc3ccccc32)n1</smiles>

Histone deacetylases (HDACs) are a type of enzymes involved in the acetylation of histones in cells, and they could catalyze the deacetylation of lysine (Lys) residues, predominantly in histones $\left[\mathrm{H}^{3}\right]$ and $\left[\mathrm{H}^{4}\right]$ dopamine, which is one of the key steps in the regulation of expression of target genes affecting proper cell function, differentiation, and proliferation. The abnormal recruitment of HDACs has been clearly linked to carcinogenesis. Therefore, small molecules with HDACs inhibitory ability have potent anticancer effect. Benzotriazole based trimethoxybenzoate 3 exhibited a considerable HDAC inhibitory activity $\left(\mathrm{IC}_{50}=9.4 \mu \mathrm{g} / \mathrm{mL}\right)$ as well as a remarkable antiproliferative activity with a mean $\mathrm{IC}_{50}$ value of $1.7 \mu \mathrm{g} / \mathrm{mL}$ against three human cancer cell lines including oral epidermoid carcinoma KB cells, nonsmall-cell lung carcinoma H460 cells and stomach carcinoma MKN45 cells, which was close to the value of positive control doxorubicin. However, the replacement of ester moiety by amide fragment gave another benzotriazole derivative with less antiproliferative activity [35]. This indicated that the antiproliferative function of this compound was possibly associated with its significant HDAC inhibitory activity. Furthermore, the docking study confirmed that the two oxygens of ester in compound 3 could form hydrogen bonds with the amino hydrogens of His170 and Phe198, respectively. Moreover, positive -stacking interactions were existed between two benzene rings of this molecule and Tyr264. In addition, the benzotriazole ring and benzene ring of compound 3 may form a hydrophobic interaction with Phe141, Tyr196, Leu265, Lys267, and Tyr297 of the enzyme. The different polarities and sizes of the substituents in the benzene ring and benzotriazole ring are also important factors to influence the $\mathrm{H}$-bonds and $\pi-\pi$ interactions, leading to the differences in HDAC inhibitory activity of these compounds.<smiles>COc1cc(C(=O)On2nnc3ccccc32)cc(OC)c1OC</smiles>

Focal adhesion kinase (FAK) is a non-receptor tyrosine kinase that makes great difference in cell proliferation, survival, motility, invasion, metastasis, and angiogenesis, which could form important cell signal transduction pathways. Enhanced FAK signaling may result in uncontrolled proliferation, survival or migration of cells, as observed in the development and progression process of cancers. Therefore, FAK is a promising target for cancer treatment. Oxadiazoles have been drawn much attention as medical agents during the past decades because of their wide spectral bioactivities. Benzotriazole containing 1,3,4-oxadiazole derivative 4 exhibited good FAK inhibitory activities with $\mathrm{IC}_{50}$ values ranging from 0.9 to $1.5 \mu \mathrm{mol} / \mathrm{L}$. Importantly, this compound also gave potent inhibitory activity against MCF-7 and HT29 cell lines with IC $_{50}$ values of 5.68 and $10.21 \mu \mathrm{g} / \mathrm{mL}$, respectively. The apoptosis evaluation analyzed by flow cytometry demonstrated that this compound effectively induced apoptosis of MCF-7 cells [36]. Further docking mode of compound 4 into FAK showed that it could nicely bind to the FAK protein catalytic subunit through two interaction bonds with low interaction energy. The molecular docking results, along with the biological assay data, suggested that compound 4 should be a potential inhibitor of FAK. These results provide a theoretical basis for further structural optimization of 1,3,4-oxadiazole benzotriazole derivatives as FAK inhibitors in the treatment of cancers.<smiles>Fc1ccccc1CSc1nnc(Cn2nnc3ccccc32)o1</smiles>

The efficiency of cancer chemotherapy is usually impaired by drug resistance. Benzotriazole derivative 5 was designed and synthesized to enhance the chemosensitizing activity to combat drug resistance. The in vitro evaluation indicated that compound 5 could inhibit $29.9 \%$ of cell growth in murine lymphocytic leukemia cell line P388, which was higher than the standard drug Verapamil (9.3\%) at the concentration of $80 \mu \mathrm{g} / \mathrm{mL}$ [37]. The lipophilicity of benzotriazole and its ability to act as a hydrogen bond acceptor may improve its anticancer efficiency. Further researches are worthwhile to focus on the design of new structural anticancer benzotriazole derivatives to reduce their inherent cytotoxicity and increase the chemosensitizing activity.<smiles>COc1ccc2cc(C(=O)NCCCn3nnc4ccccc43)ccc2c1</smiles>

Microtubules as cytoskeletal filaments are an important factor in the regulation of processes including cell shape maintenance, segregation of chromosomes during mitosis, location of membranebound organelles and transportation. Attacking the microtubule system is a common strategy to inhibit the proliferation of tumor cells. However, the prolonged use of tubulin-targeting agents results in drug resistance in cancer cells. Therefore, a lot of researches have been devoted to exploit novel tubulin inhibitors capable to effectively overcome drug resistance, then improving their clinical efficacy. Benzotriazole acrylonitrile 6 exhibited stronger anticancer activities in comparison to the standard drug etoposide and greater potential than 6-mercaptopurine against a series of human cell lines including splenic B-lymphoblastoid cells, acute B-lymphoblastic leukemia, skin melanoma and breast adenocarcinoma with the median cytotoxic concentrations $\left(\mathrm{CC}_{50}\right.$ values) ranging from 0.05 to $0.8 \mu \mathrm{mol} / \mathrm{L}$ [38]. Further molecular docking model investigations once more confirmed the ability of compound 6 to inhibit the polymerization of tubulin, thereby preventing the formation of spindle cells by blocking cell replication in its metaphase. In order to further deduce the structureactivity relationship, a series of benzotriazole derivatives were synthesized and the results showed that the replacement of methoxy moiety by methyl group, chlorine or bromine atom on the benzene ring reduced the antiproliferative ability.<smiles>COc1ccc(/C=C(\C#N)n2nnc3ccccc32)cc1</smiles>

Benzotriazole-substituted benzoate derivative 7 a was synthesized and evaluated for its anti-proliferative activity against several cancer cell lines. It could effectively inhibit the proliferation of human 
hepatocarcinoma BEL-7402 cell with low $\mathrm{IC}_{50}$ value of $0.082 \mathrm{mg} / \mathrm{mL}$ [39]. Moreover, the human hepatocarcinoma BEL-7402 cell line was selected as a model to illustrate inhibition effect of compound $7 \mathrm{a}$ as well as its potential mechanism, which was the highest susceptible cell line to this compound. The results showed that it could inhibit the proliferation of BEL-7402 cells, and the cell death may occur through the modulation of mitochondrial functions regulated by reactive oxygen species. Further structural modification suggested the replacement of benzene ring with pyridine and exchange the methoxy into methyl group gave compound $7 \mathrm{~b}$, which could significantly reduce the viability of the breast cancer cell $4 \mathrm{~T}-1$ and possessed a time-quantity efficiency relationship [40]. These benzotriazole derivatives are potent for developing safer agents to treat different kinds of cancers. The action mechanism is currently unclear.

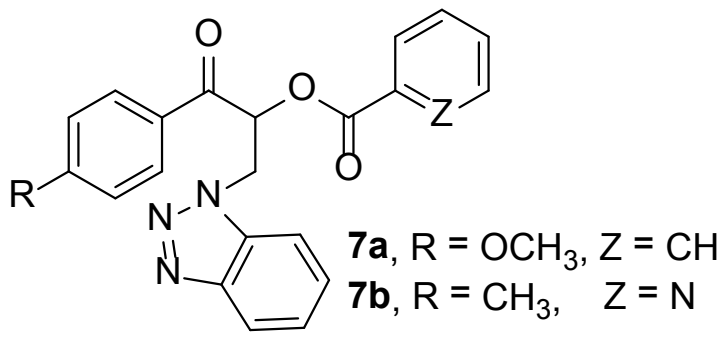

DNA intercalators have played a key role in the treatment of cancers. For instance, amsacrine as an acridine could bind to DNA and exhibit good inhibition towards the enzyme topoisomerase II, which could form the prototype for a series of new clinical agents. Benzotriazole containing aminoacridine derivative 8 was efficiently synthesized by benzyne click chemistry, and it exhibited moderate anticancer efficiency against human leukaemia cell line HL60 $\left(\mathrm{IC}_{50}=23.4 \mu \mathrm{mol} / \mathrm{L}\right)$ [41]. However, when the carboxamide moiety at 4-position was changed into its 3-position, the anticancer activity greatly decreased $\left(\mathrm{IC}_{50}=262.4 \mu \mathrm{mol} / \mathrm{L}\right)$. Researches show that this compound could bind to duplex DNA, while the biological target (DNA or topoisomerase) is not clear and needs further investigations.

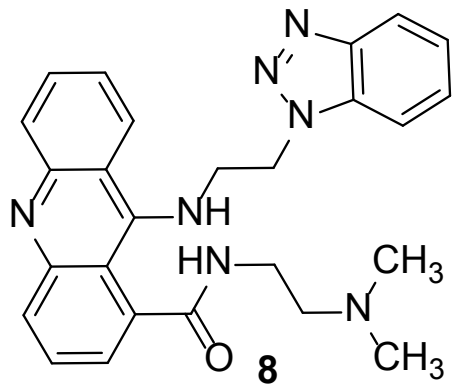

Nitrogen heterocyclic steroids have recently become a hot topic due to the ability to treat breast cancer, prostate cancer, leukemia, autoimmune diseases, and osteoporosis. The combination of azole rings with the steroid backbone could afford bioactive compounds with potent inhibition against the important anticancer target $17 \alpha$-hydroxylase- $C_{17,20}$-lyase via different functional groups located around the periphery of their rigid tetracyclic core, thus exhibiting large potentiality in the treatment of breast cancer, prostate cancer and so on. Benzotriazole-based androstane aminosteroid 9 showed high potency to inhibit human cervical cancer cells (HeLa), human colon adenocarcinoma cells (SW480), human lung carcinoma cells (A549), human hepatic carcinoma cells (HepG2) and human cervical cancer cells $(\mathrm{SiHa})$ with $\mathrm{IC}_{50}$ values of $5.12-18.63 \mu \mathrm{mol} / \mathrm{L}$ [42]. Aromatic amines at C-3 position as well as benzotriazole ring at C-16 position might be helpful to improve the potency against cancer cell lines.<smiles>CC(=O)OC1[C@H](n2nnc3ccccc32)C[C@H]2C3CCC4CC(N(C)c5ccccc5)CC[C@]4(C)C3CC[C@]12C</smiles>

Metal cations have been proved to be helpful to neutralize the negative charge of DNA, which may be responsible for the improvement of the physicochemical activities of compounds like solubility or bioavailability attributing to the interaction with DNA via reversible intermolecular associations [43]. The complexes of transition metal ion and organic ligand could not only stabilize the cleavable complex formed between enzyme and DNA, but also control the replication and transcription of DNA in malignant tumor cells, thus showing more active anticancer efficiency than the ligand alone [44]. Recently, some benzotriazole derivatives have been employed to form metal complexes with anticancer activities.

The combination of iron ion and the salen ligand (salen=N,N'ethylenbis (salicylaldimato) dianion)) gives $\left[\mathrm{Fe}(\text { salen) }]^{+}\right.$cation, which have been extensively researched since 1933 . The special structural $\mathrm{N}$-donor based transition metal complexes with unpaired electrons in their valence shells involving in polymeric chains often possess notable biological activities, such as superoxide dismutase (SOD) mimic activity and DNA cleavage activity. The interaction of anionic bridging ligand benzotriazole into the iron-salen action would lead to the formation of a novel group of polymeric iron-salen complexes with potent anticancer activity. For example, benzotriazole based $\mathrm{Fe}(\mathrm{III})$-salen-like complex 10 with one-dimensional [Fe(salen) (btriz) $]_{n}$ chain displayed notable anticancer activity against human cancer cell lines chronic myelogenous erythroleukemia K562 and breast adenocarcinoma MCF7 with $\mathrm{IC}_{50}$ values of 10.9 and $16.9 \mu \mathrm{g} /$ $\mathrm{mL}$, respectively [45]. Further study exhibited that this complex with certain superoxide dismutase (SOD) mimic activity was responsible for the local imbalance in superoxide/hydrogen peroxide levels, leading to apoptosis of the target cells. The DNA cleavage evaluation also explained the possible mechanism of apoptosis of target cancer cells caused by this complex. These preliminary results suggested that benzotriazole-based metal complex 10 should be indeed a promising candidate and worthy of further in vitro and in vivo preclinical studies.

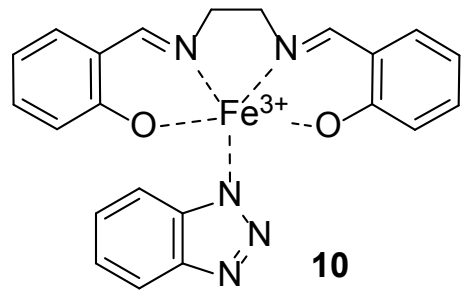

Benzotriazole containing drometrizole and its derivatives represent as an important class of industrial additives for polymers with strong absorption of ultraviolet light. Therefore, this type of compounds is ready to coordinate with metal ions to exhibit some potent bioactivities. For example, the new structural complex 11 with $\mathrm{Ag}^{+}$ion showed considerable anticancer efficacy toward the human breast cancer (MDA-MB231) and human ovarian cancer (OVCAR-8) cell lines with $\mathrm{IC}_{50}$ values of 14.13 and $13.54 \mu \mathrm{mol} / \mathrm{L}$, which were much stronger than the standard drug cisplatin ( IC $_{50}=32.0$ and $30.86 \mu \mathrm{mol} / \mathrm{L}$, respectively). More importantly, this compound possessed very low toxicity toward normal human breast and ovarian cell lines [46]. 


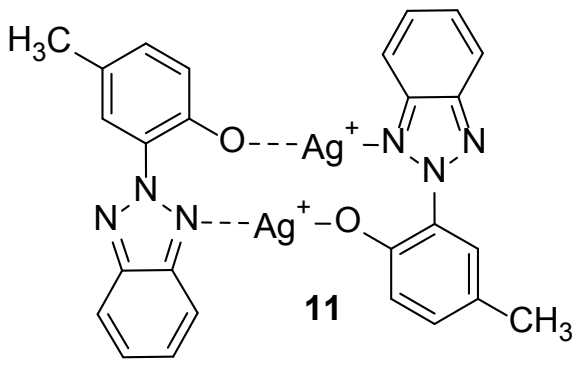

In recent decades, different types of ferricenium salts have been synthesized and found to possess various bioactivities such as antitumor and antianemic activities, demonstrating membrane permeability, and low toxicity. Azole compounds as the central ingredients in many drugs have been commonly used in structural modification of ferrocene to produce complexes with enhanced anticancer effect. Among them, ferrocenyl benzotriazole derivative 12 showed inhibition against different human cancers including non-small-cell lung cancer, endometrial cancer and esophageal cancer with a percentage of $100 \%$ [47], which was even better than the standard drug cisplatin. Further evaluation indicated that the benzotriazole moiety contributed to its high bioactivity since it provided a transport for the lipophilic ferrocenyl moiety to ensure the membrane permeability. Moreover, the plane hydrophilic structure of benzotriazole could intercalate into the planes of DNA nucleic bases, and also form hydrogen bonds with phosphate groups at cleavage points of DNA, thus enhancing its anticancer activity.<smiles>CC(c1ccccc1)n1nnc2ccccc21</smiles>

\section{Antifungal Benzotriazoles}

Fungal infections are a kind of quite prevalent diseases $[48,49]$. Among different kinds of antifungal agents, azole compounds have been rapidly developed as the mainstream for fungal infection treatment and are widely used in clinic [50-52]. Benzotriazole with a benzene ring endures a larger conjugated system than triazole or imidazole as well as a three-nitrogen containing structure could more readily bind with the receptors in organisms with less toxicity. A lot of researches and exploitations have been devoted to benzotriazoles due to their potentiality as novel antifungal agents [53-55].

\section{Structural modification of clinical antifungal drugs by benzotriazole ring}

A variety of antifungal azoles representing as an important class of nitrogen-containing heterocycles with desirable electron-rich properties, have been early discovered and successfully used to develop clinical agents [56-59]. With the growing emergence of the intrinsic and acquired antifungal resistance caused by the abuse of available drugs, especially the multidrug-resistant fungi (Figure 2), it is urgent to develop novel structural agents with more efficiency, less toxicity, better lipophilicity and stronger antifungal ability [60]. Notably, the structural modification of clinical azole antifungal drugs like fluconazole and clotrimazole is regarded as a helpful strategy to improve their physicochemical property and binding affinity, overcome their shortcomings, and effectively broaden their antifungal spectrum [61].

Fluconazole is a first-line oral triazole-antifungal drug recommended by WHO, and could effectively inhibit the growth of Candida albicans (C. albicans) and Cryptococcus neoformans (C. neoformans) by displacing lanosterol from cytochrome $\mathrm{P}^{4} 0_{14 a \mathrm{DM}}$, blocking the biosynthesis of ergosterol which is the essential component of the fungal cell membrane, then destroying the integrity of the fungal cell wall and inhibiting the growth and breeding of fungi [62]. However, the treatment efficiency of fluconazole with poor water solubility is limited against some resistant fungal stains like invasive Aspergillosis niger (A. niger) [63]. Moreover, the azole resistant fungi developing in protein regions involved in orchestrating passage of CYP51 through different conformational stages along with the catalytic cycle rather than in residues contact with fluconazole directly [64]. The structural modification of fluconazole is a useful way to explore novel antifungal agents. Recently, some researches have introduced benzotriazole ring into fluconazole to improve its bioactivity. For example, methyl benzotriazole substituted fluconazole derivative 13a showed the increased antifungal activity against Candida glabrata $(C$. glabrata) ATCC 3916 with the minimum inhibitory concentration (MIC value) of $25 \mu \mathrm{g} / \mathrm{mL}$, which was at least two-fold more potent than fluconazole. The introduction of a methyl group into benzotriazole ring of compound 13a at 5-position yielded fluconazole analog 13b with much more superior antifungal activity $(\mathrm{MIC}=12.5 \mu \mathrm{g} / \mathrm{mL})$ to fluconazole (MIC>100 $\mu \mathrm{g} / \mathrm{mL}$ ) against A. niger DSMZ 737 [65]. When the methyl group on benzotriazole was replaced by other groups such as nitro or methoxy group, the inhibition against $A$. niger considerably reduced, but without significantly affecting their inhibitory activities against Candida spp. Moreover, compounds containing small hydrophobic groups on its benzotriazole ring displayed remarkably enhanced antifungal activity against $A$. niger, whereas its inhibitory activity against Candida spp. slightly decreased. The structure activity relationship suggested that small hydrophobic methyl group on the benzotriazole ring made contributions to their inhibitory activity against both Candida and Aspergillus. These results also indicated the importance of the 5-position occupied benzotriazoles in improving antifungal activities. Further docking molecular dynamics simulations of compound $13 \mathrm{~b}$ with the active sides of cytochrome P450 14 $\alpha$-sterol demethylase from Mycobacterium tuberculosis (MTCYP51) demonstrated that one methyl group in benzotriazole formed hydrophobic interaction with Val434, while the other methyl group established hydrophobic contacts with Leu321, Ile323, and Leu324, thus exerting good inhibitory activity against both Candida and Aspergillus spp.
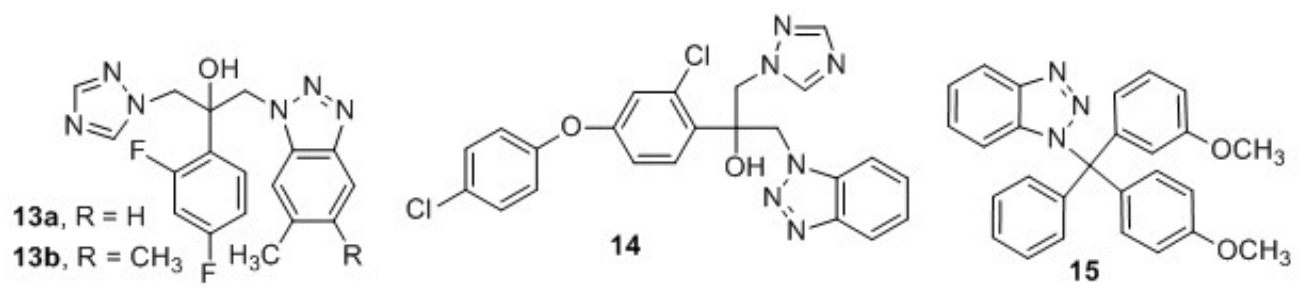

Figure 2: Structural Modification of Clinical Antifungal Drugs by Benzotriazole Ring. 
<smiles>[R][R](=C)[14CH3]</smiles>

The triazolyl ethanol moiety in fluconazole plays an important role in arresting the sterol biosynthesis by inhibiting the activity of $14 \alpha$-demethylase $(14 \alpha$-DM) which is a specific cytochrome $\mathrm{P} 450$, and it is helpful to enhance the bioactivity of many antifungal azole compounds such as tebuconazole, flutriafol, hexaconazole and cyproconazole [66]. In addition, the aryl phenyl ether group is a highly efficient pharmacophore and is widely used in pesticides and drug molecules. In view of this, the novel benzotriazole derivative 14 as a fluconazole analog was synthesized and could inhibit the growth of C. arachidicoa in percentage of $62.7 \%$, which was better than the commercial fungicide difenoconazole. However, the replacement of benzotriazole ring by other moiety with smaller groups such as alkyl amino, alkoxy, triazolyl or substituted benzyl substituents could favorably inhibit the oxidative remove of sterol C(14) methyl groups by the cytochrome P450 enzyme, thus enhancing the antifungal activity $[67,68]$.<smiles>OC(Cn1cncn1)(Cn1nnc2ccccc21)c1ccc(Oc2ccc(Cl)cc2)cc1Cl</smiles>

Clotrimazole is an extensively used antifungal azole drug in clinic. As an effective inhibitor of lanosterol $14 \alpha$-demethylase (cytochrome
P-45014 $\alpha$-DM), its related researches received continuously increasing interest. Benzotriazole substituted clotrimazole 15 bearing two methoxyl groups displayed equivalent anti-Trichophyton rubrum (T. rubrum) activity to the standard fluconazole ( $\mathrm{MIC}=32 \mu \mathrm{g} / \mathrm{mL}$ ). However, the remove of the methoxyl group resulted in obviously decreased antifungal efficiency. Docking score showed that this compound could effectively bind to the active sites of the cytochrome P450 $14 \alpha$-sterol demethylase [69]. It revealed some correlations between the antifungal activity of this compound and its docking energy. The three-nitrogen and aromatic structural benzotriazole in this molecule may be helpful to bind with heme iron of enzyme, therefore being capable to exert its antifungal activities.<smiles>COc1ccc(C(c2ccccc2)(c2cccc(OC)c2)n2nnc3ccccc32)cc1</smiles>

\section{New structural benzotriazoles as antifungal agents}

The combination of multiple functional groups with different action modes into one molecule could produce new antifungal agents [70]. Heterocyclic molecules usually containing N, O or S heteroatom in their cyclic structures as one of the most active classes of compounds possess a wide spectrum of biological activities, and have showed large potentiality in pharmaceutical science (Figure 3). The introduction of benzotriazole ring into other heterocyclic scaffolds to form some new structural compounds with improved antifungal ability has attracted increasing attention in medicinal chemistry, and this field is worthy of further investigations [71].

The modification by the alkyl or aryl halide could result in good antifungal activities. Aryl halide benzotriazole derivative 16 displayed comparable antifungal efficacy against Microsporum canis to the<smiles>Clc1ccc(C(c2ccccc2)n2nnc3ccccc32)cc1</smiles><smiles>[R]c1ccccc1-c1nnc(Cn2nnc3ccccc32)o1</smiles><smiles>[R]c1cccc2c1nnn2CC(=O)N1C(=O)CC(=O)N1c1ccc(Cl)cc1</smiles>

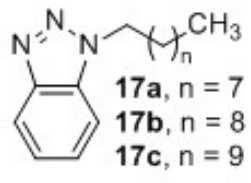<smiles>Cc1ccnc(NCn2nnc3ccccc32)c1</smiles><smiles>[R]c1nc2cc(C)ccc2n1Cn1nnc2ccccc21</smiles>

20a, $\mathrm{R}=\mathrm{CH}_{2} \mathrm{CH}_{3}$ 20b, $R=$<smiles>Cc1cccnc1</smiles><smiles>O=C(Cn1nnc2ccccc21)NN1C(=O)C(Cl)C1c1ccccc1Cl</smiles>

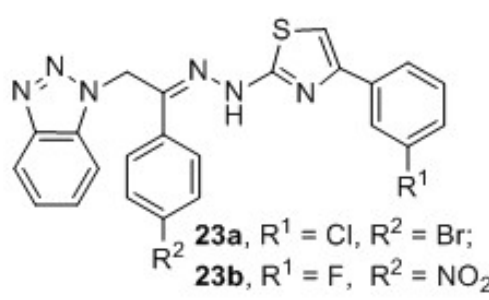<smiles>O=C1N(c2ccccc2)C(=O)C(c2ccccc2)(c2ccccc2)N1Cn1nnc2ccccc21</smiles>

Figure 3: New Structural Benzotriazoles as Antifungal Agents. 
standard drug griseofulvin with an MIC value of $2 \mu \mathrm{g} / \mathrm{mL}$ [72]. Further docking study revealed that it could easily bind with the active sites of MT-CYP51 with a rather negative docking energy, which was an essential enzyme in the sterol biosynthetic pathway of eukaryotes and inhibited by azole antifungal drugs. The benzotriazole ring and chlorophenyl group of this molecule may be beneficial to its antifungal activity.<smiles>Clc1ccc(C(c2ccccc2)n2nnc3ccccc32)cc1</smiles>

Some benzotriazole derivatives with different lengths of alkyl chains were reported to have moderate to good activity against species of Candida and Dermatophytes. Alkyl benzotriazole 17a considerably inhibited the growth of fluconazole and itraconazole-insensitive $C$. neoformans $(\mathrm{MIC}=2 \mu \mathrm{g} / \mathrm{mL}$ ). Besides, compound $17 \mathrm{~b}$ with a longer alkyl chain possessed moderate inhibitory efficacy against Microsporum gypseum $(\mathrm{MIC}=32 \mu \mathrm{g} / \mathrm{mL})$. However, benzotriazole derivative $17 \mathrm{c}$ with a much longer alkyl chain showed no antifungal activity against all the tested fungal strains [73]. The structure activity relationship suggested that the long alkyl chains were unfavorable for their antifungal activity.

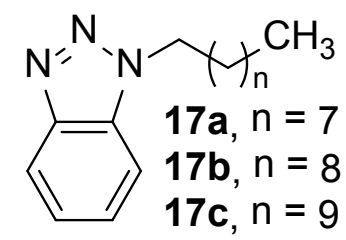

Pyridine derivatives have been used to develop many analogues, particularly to study the nuclear and side-chain substitution effects on biological activities. Modification on the pyridine nucleus by benzotriazoles can afford new classes of therapeutically active compounds for fungous infections. For example, the introduction of benzotriazole into the amino pyridine ring endowed compound 18 with strongest fungal inhibitory among all the new synthesized compounds, like the thiophenol containing one [74]. Compound with a methyl group at 4-position in pyridine ring gave better antifungal activity than derivative at 3-position. Moreover, the introduction of 1-hydroxymethyl benzotriazole on the amino group of pyridine showed better antifungal activity than that on the carbon atom of pyridine. This type of compounds has opened up the possibility of their potential use as a novel class of totally synthetic antimicrobial agents active against plant pathogenic fungi.<smiles>Cc1ccnc(NCn2nnc3ccccc32)c1</smiles>

Oxadiazole is a special structural fragment for designing potential bioactive agents, which has been reported to exhibit potent antifungal effects. The new synthesized benzotriazole containing phenyl substituted 1,3,4-oxadiazole derivative 19a exhibited good antifungal activity against $C$. albicans, A. niger and A. flavus with bigger zones of inhibition than the standard drug streptomycin. When the phenyl group of 19a was changed into chlorophenyl moiety, compound $19 \mathrm{~b}$ was obtained with a better antifungal efficiency than 19a against the tested strains [75]. It could be seen that chlorine substituted aromatic compound was more active than unsubstituted one.<smiles>[R]c1ccccc1-c1nnc(Cn2nnc3ccccc32)o1</smiles>

Methyl benzimidazole derivatives are deeply investigated as antimicrobial agents [76,77]. The combination of benzotriazole and substituted methyl benzimidazole via a methylene group yielded their hybrids with good inhibition against a broad range of fungi, such as $P$. oryzae, B. cinerea, A. niger, C. albicans and T. rubrum. Benzimidazole substituted benzotriazole derivative 20a exhibited a satisfactory inhibition against $P$. oryzae, which was better than the commercial fungicide griseofulvin. The replacement of ethyl group into 3-pyridyl moiety gave compound 20b with a comparable antifungal activity against $B$. cinerea to griseofulvin [78]. The antifungal activities of these compounds may be attributed to the presence of methyl, ethyl or 3-pyridyl group in benzotriazole ring.

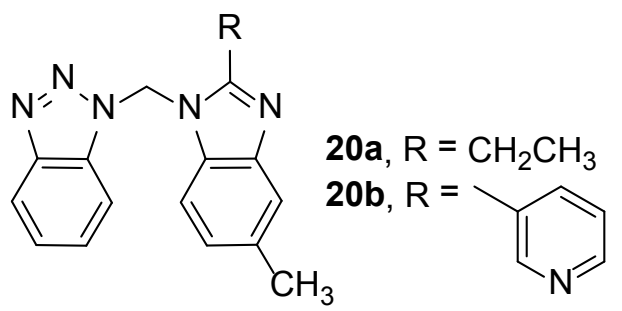

The 3-chloro monocyclic $\beta$-lactam heterocycles with various substituents at 1 - and 4 - positions are an important group in many clinical antibiotics [79]. The structural modification of $\beta$-lactam ring by other pharmacophores could improve the bioactive efficiency [80]. The benzotriazole substituted $\beta$-lactam 21 exhibited moderate to good in vitro antifungal activities in comparison to the reference drug fluconazole against the tested strains C. albicans. This compound could also effectively bind with the active sites of the cytochrome P450 with a rather negative docking energy [81]. The replacement of the chlorine atom on benzyl ring by other electron withdrawing substituent such as nitro group resulted in a reduced antifungal efficiency. Benzotriazole ring may impart the lipophilicity of the molecule to enhance its fungal inhibition.<smiles>O=C(Cn1nnc2ccccc21)NN1C(=O)C(Cl)C1c1ccccc1Cl</smiles>

Pyrazolidine-3,5-dione derivatives as angiotensin II receptor antagonists possess an inclusive range of antimicrobial activities. Pyrazilidin-3,5-dione substituted benzotriazole derivative 22a exhibited the same activity with the standard drug clotrimazole against $C$. albicans. The introduction of a chlorine atom at 4-position of benzotriazole in 22a yielded compound 22b with more effective inhibition against $C$. albicans than clotrimazole [82]. These results demonstrated that the combination of pyrazolidine-3,5-dione moiety and benzotriazole, especially the chlorine substituted benzotriazole, highly contributed to the antifungal activity of the prepared compounds. 
Further investigation with appropriate structural modification of these compounds may result in therapeutically useful products.<smiles>[R][R20]#[R20]</smiles>

Thiazole represents an overwhelming and rapidly developing part in modern heterocyclic chemistry, and thiazole containing compounds as medicinal agents exert important bioactive activities such as antitumor, anticonvulsant, cardiotonic, IMP dehydrogenase inhibition and analgesic activities. The combination of benzotriazole and thiazole in a single molecule may generate innovative bioactive drugs. In addition, the carbon-nitrogen double bond of hydrazone constitutes an important class of compounds for the development of new drugs. For these reasons, hydrazone containing thiazolyl-benzotriazoles $23 \mathrm{a}$ and $23 \mathrm{~b}$ were synthesized with moderate to good fungal inhibitions against A. niger and C. albicans with MIC values in the range of $2-128 \mu \mathrm{g} /$ $\mathrm{mL}$ [83]. The existence of hydrazone containing azomethine fragment and electrophilic atoms such as fluorine or chlorine are helpful to the enhancement of antifungal abilities.

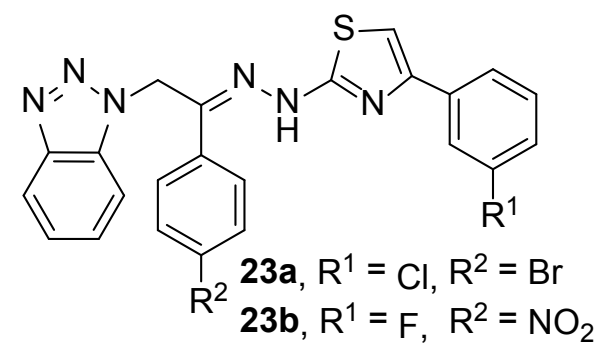

Hydantoin or imidazoline-2,4-dione is a common 5-membered ring containing a reactive cyclic urea core and its derivatives are widely used to treat fungous infections due to their low cytotoxicity and advanced antifungal activity. Benzotriazole modified hydantoin 24 was prepared by Mannich reaction in an unconventional microwave method and it possessed equivalent antifungal activities to the standard drug griseofulvin with comparable zones of inhibition against the tested strains. Further structure-activity relationship researches found that the introduction of benzotriazole into hydantoin could retain or increase the activity against both C. albicans and A. niger [84].<smiles>[Z4]CN1C(=O)N(Cn2nnc3ccccc32)C(c2ccccc2)(c2ccccc2)C1=O</smiles>

In addition, many other types of benzotriazole derivatives with good antifungal activities have exerted their potentiality and the relating researches have been deeply investigated in recent years, and have brought a new hope for the antifungal battles [85].

\section{Benzotriazole-containing metal complexes as antifungal agents}

Metal cations have been found to be helpful to neutralize the negative charge of DNA and the complexes of transition metal and organic antifungal ligands are more active against fungal strains than the ligands alone (Figure 4). The enhanced antifungal efficacy may be responsible for the improvement of the physicochemical properties such as solubility or even bioavailability and attribute to the interaction with DNA via reversible intermolecular associations. In recent years, screening for high profile antifungal candidates with strong pharmacological activity, low toxicity, few side effects and high bioavailability from bioactive metal complexes have become one of the most effective methods to design and synthesize novel structural antifungal drugs.

Triazole derivatives are versatile ligands since they could provide not only multi-coordinated sites to link more metal centers but also excellent $\pi-\pi$ stacking interactions between the rings to generate multi-nuclear complexes or polymers. Triazole-based complexes are a kind of important antimicrobial supramolecular agents, which could unite the coordination geometry of both pyrazoles and

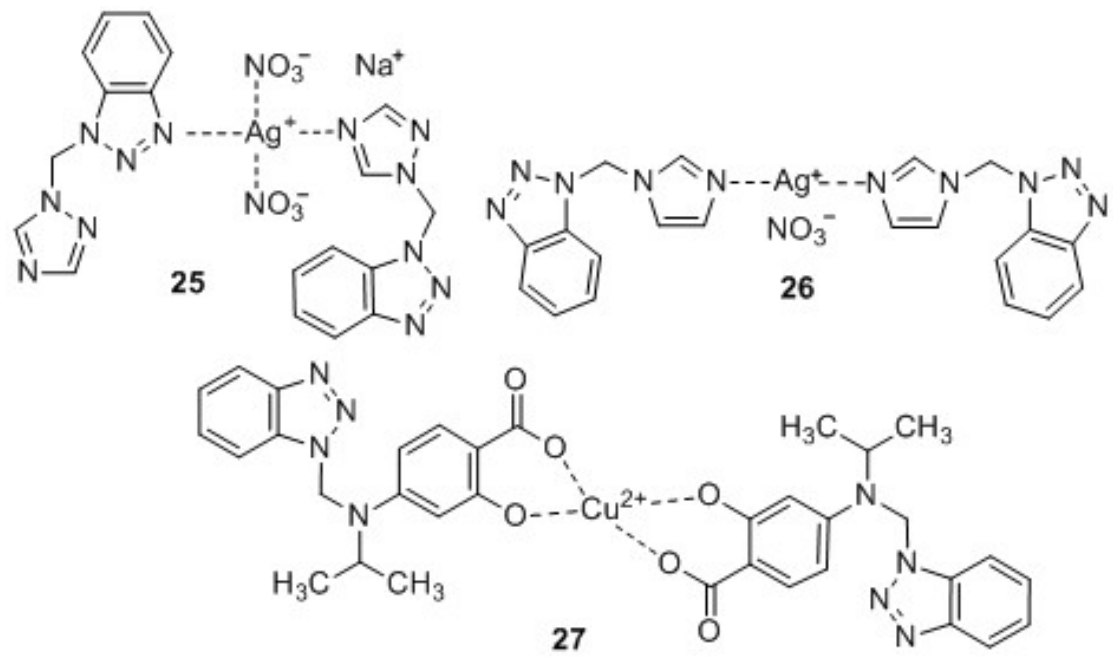

Figure 4: Benzotriazole-Containing Metal Complexes as Antifungal Agents. 
benzotriazoles and exhibit a strong and typical property of action as bridging ligands metal ions, such as $\mathrm{Ag}(\mathrm{I})$ and $\mathrm{Cu}(\mathrm{II})$ ions. The $\mathrm{Ag}(\mathrm{I})$ (triazole)-1-benzotriazole complex 25 displayed $86.1 \%$ inhibitory effect against Physalospora piricola as well as good antifungal activity against other strains including Gibberalla zeae, Fusarium oxysporum, Cercospora rachidicola and Alternaria solani [86]. This complex gave lower bioactivities than the corresponding inorganic salt $\mathrm{AgClO}_{4}$. The replacement of benzotriazole ring in the ligand by pyridazine group reduced the antifungal activity. Benzotriazole ring may affect the coordination configuration and antifungal activity of this metal complex.

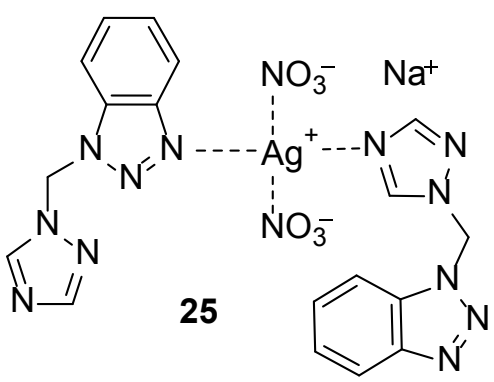

Silver(I) ion with soft acidic property could easily coordinate with $S$ - or $N$-donors. In recent years, silver(I) complexes have been investigated very well for their bioactivities. Azole-based silver supermolecules have been found to have various antimicrobial activities. Benzotriazole-containing Ag(I) complex 26 exhibited much higher antifungal activity than the ligand against Physalospora piricola and Alternaria solani with inhibitory percentage of $88 \%$ and $75 \%$, respectively [87]. The exchange of $\mathrm{Ag}^{+}$ion into other metal ions such as $\mathrm{Co}^{2+}$ ion decreased its antifungal activity, which suggested that the $\mathrm{Ag}^{+}$ ion as a metal center of this benzotriazole-containing complex should play a vital role in exerting the antifungal efficiency. The benzotriazole substituted ligand acted as a good electron donor and provided weak interactions such as $\pi-\pi$ interactions, hydrogen bonds, and $\mathrm{C}-\mathrm{H} \cdots \pi$ interactions to assemble high dimensional coordinated polymer.<smiles></smiles>

The $\mathrm{Cu}(\mathrm{II})$ complex of benzotriazole derivative 27 showed potentially antifungal activities against Penicillium expansum, Botrydepladia thiobromine, Nigrospra sp., Trichothesium sp. and Rhizopus nigricans, which were much stronger than its precursor benzotriazole ligand alone. The fungal inhibitory reduced when $\mathrm{Cu}^{2+}$ ion was changed into other transition metal ions such as $\mathrm{Mn}^{2+}, \mathrm{Co}^{2+}$, $\mathrm{Ni}^{2+}$ or $\mathrm{Zn}^{2+}$ ions [88].<smiles>CC(C)N(Cn1nnc2ccccc21)c1ccc2c(c1)O[C@H]1COc3cc(N(Cn4nnc5ccccc54)C(C)C)ccc3C(=O)O[C@H]1O2</smiles>

As mentioned above, benzotriazole metal complexes displayed great potentialities in searching for high profile antifungal candidates. However, the relative researches and developments are not enough and still in its initial stage. Much attention should be paid on this strategy to find out benzotriazole complexes with good curative effects, low toxicity, especially little resistance.

\section{Antibacterial Benzotriazoles}

Bacterial infections are frequently occurring infective diseases all around the world, particularly in Indian subcontinent, portions of South America and tropical fraction of Africa. The morbidity and mortality caused by food poisoning, rheumatic, salmonellosis of diarrhea from bacterial infection are the major healthy problems $[89,90]$. Despite a lot of antibiotics and chemotherapeutics like beta-lactams, tetracyclines, aminoglycosides, macrolides, polyenes etc. and synthetic drugs such as sulfonamides, quinolones, oxazolidones, allylamines and so on are available for clinical use, the treatment of bacterial infectious diseases still remains an important and challenging problem due to a series of factors such as emerging infectious diseases, severely adverse effects, narrow antibacterial spectrum as well as single dosage form [91,92]. More importantly, an increasing number of multidrug resistant microbial pathogens like methicillin-resistant Staphylococcus aureus (MRSA) and carbapenems-resistant Enterobacteriaceae force a real need to develop new compounds acting through distinct mechanisms from the well-known classes of antibacterial agents. The development of benzotriazole derivatives as antibacterial drugs has become a rapidly developing field with considerable breakthroughs [93].

\section{Structural modification of clinical antibacterial drugs by benzotriazole ring}

Structural modification of clinical antibacterial drugs to broaden their antimicrobial spectrum and increase therapeutic indexes has provoked special interest in the realm of medicinal chemistry [94]. Some researches have manifested that the incorporation of benzotriazole ring into clinical drugs could evidently improve their antibacterial efficiency and reduce cytotoxicity (Figure 5).

Quinolones as essential antibacterial agents are of great importance in clinic. Levofloxacin is one of the third generation of fluoroquinolone antimicrobial drugs, which has been widely used in the treatment of bacterial infections due to its great inhibitory activity against both Gram-positive and Gram-negative bacteria via inhibiting DNA gyrase (Figure 6). Recently, extensive effort has been devoted to the structural modifications of levofloxacin with the aim to reduce its side effects, and maintain or enhance its antibacterial activities. The newly synthesized amino benzotriazole substituted levofloxacin quinolone derivative 28 was as effective as ofloxacin against Gram-positive bacteria (MRSA) and Gram-negative bacteria (Proteus spp.) with similar zones of inhibition, which revealed that the introduction of amino benzotriazole group in levofloxacin could improve antibacterial activity via the enhanced interactions with target enzymes or penetration into bacteria [95]. This work has successfully introduced new substituted amine appendages at C-3 position of fluoroquinolone nucleus and produced new levofloxacin derivative with considerable antibacterial activity.<smiles>CC1COc2c(N3CCN(C)CC3)c(F)cc3c(=O)c(C(=O)Nn4nc5ccccc5n4)cn1c23</smiles>

Berberine is a well-known natural iso-quinoline alkaloid with a variety of bioactivities, it has been playing considerable roles in the treatment of infectious diseases such as acute gastroenteritis, cholera and bacillary dysentery [96-98]. The incorporation of benzotriazole 
<smiles>CC1COc2c(N3CCN(C)CC3)c(F)cc3c(=O)c(C(=O)Nn4nc5ccccc5n4)cn1c23</smiles>

28<smiles>COc1ccc2cc3c(cc2c1OCCN(CCn1nnc2ccccc21)Cc1ccc(F)cc1F)Cc1cc2c(cc1-3)OCO2</smiles>

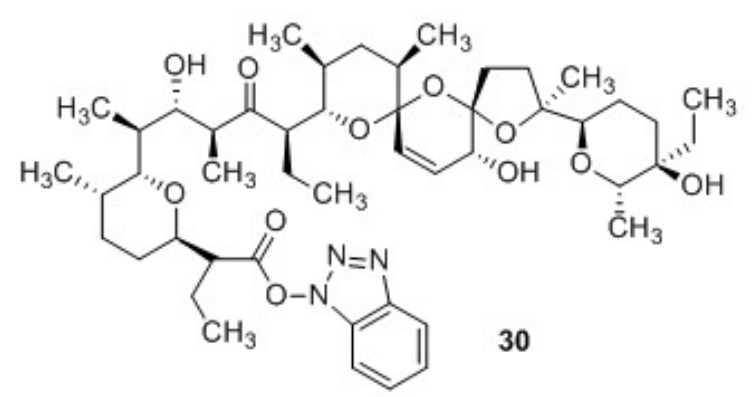

Figure 5: Structural Modification of Clinical Antibacterial Drugs by Benzotriazole Ring.<smiles>Cc1cc(=O)oc2cc(OCCn3nnc4ccccc43)ccc12</smiles>

31a<smiles>Cc1cc(=O)oc2cc(OCc3ccccc3Cn3nnc4ccccc43)ccc12</smiles><smiles>NC(c1ccc([N+](=O)[O-])cc1)n1nnc2ccccc21</smiles><smiles>[R]c1ccccc1C1SCC(=O)C1NCCCn1nnc2ccccc21</smiles><smiles>[R]c1ccc2nc3ccccc3c(-n3nnc4ccccc43)c2c1</smiles>

36a, $\mathrm{R}=\mathrm{CH}_{3}$ 36b, $\mathrm{R}=\mathrm{OCH}_{3}$<smiles>O=C(c1ccc(Br)cc1)C(Cn1nnc2ccccc21)n1cncn1</smiles><smiles>[R]C([R])(C)OC(=O)c1ccc(-c2ccc(Cn3nnc4ccccc43)cc2)cc1</smiles>

$35 b, \mathrm{R}=\mathrm{H}$<smiles>CC1=NN(C(=O)c2ccc(NCn3nnc4ccccc43)cc2)C(=O)/C1=N\Nc1cccc(S(=O)(=O)N2C[B]C([18F])C2)c1</smiles><smiles>O=C(Nc1nc(-n2cnc3ccccc32)nc(-n2nnc3ccccc32)n1)Nc1ccccc1Cl</smiles>

38<smiles>CN(C)C(=O)C(=O)N1CCC(n2nc3ccccc3n2)CC1</smiles><smiles>CCC1C(=O)C(CC)C(c2ccc(F)cc2)N(C(=O)Cn2nnc3ccccc32)C1C</smiles><smiles>CC1=NN(C(=O)c2ccc(NCn3nnc4ccccc43)cc2)C(=O)/C1=N/Nc1ccc(Br)cc1</smiles>

Figure 6: New Structural Benzotraiazoles as Antibacterial Agents.

into tertiary amino substituted berberine afforded compound 29 with good inhibitory activity against Gram-negative bacteria Shigella dysenteriae ATCC51252 (MIC $=32 \mu \mathrm{g} / \mathrm{mL})$, which was equivalent to that of the standard drug chloromycin and was four-fold higher than that of berberine $(\mathrm{MIC}=256 \mu \mathrm{g} / \mathrm{mL})$ [99]. This phenomenon clearly demonstrated that the structural modification of berberine by benzotriazole ring could effectively improve its antibacterial activity. 
<smiles>COC1=CC=C2C=C3CCc4cc5c(cc4C1=C(OCCN(CCn1nnc4ccccc41)Cc1ccc(F)cc1F)C2=CC(Cl)=N3)OCO5</smiles>

Salinomycin is a natural carboxylic polyether antibiotic isolated from Streptomyces albus, which could form hydrogen bonds between the carboxylic group on the one side of the molecule and two hydroxyl groups on the opposite side or complexes with monovalent cation (especially with $\mathrm{K}^{+}$ion), then transport them across lipid membranes. In order to develop salinomycin derivatives with promising bioactivities, a stable salinomycin benzotriazole intermediate ester 30 was unexpectedly synthesized with considerable activity against the typical Gram-positive cocci ( $\mathrm{MIC}=1-4 \mu \mathrm{g} / \mathrm{mL}$ ) [100]. Importantly, this compound is beneficial to solve the most important epidemiological problems of contemporary hospital medicine via high inhibition against a series of clinical isolates of Staphylococcus including methicillinresistant $S$. aureus (MRSA) and methicillin sensitive S. aureus (MSSA).

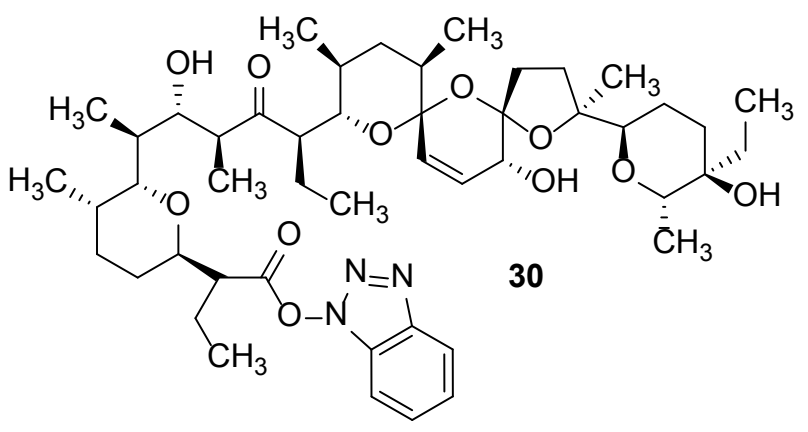

\section{New structural benzotriazoles as antibacterial agents}

Besides the researches on the structural modifications of clinical antibacterial drugs, the substitution of benzotriazole ring by other bioactive pharmacophore is another useful and efficient way to develop new categories of antibacterial agents. Recently, some researchers are engaged in the studies on heterocycle-based benzotriazole derivatives with potent antibacterial activities.

Coumarin compounds are a large class of quite important lactones structurally constructed by a benzene ring fused $\alpha$-pyrone ring with a broad range of biological activities such as anticoagulant, anti-neurodegenerative and antibacterial efficacies [101-105]. The introduction of benzotriazole into coumarin ring afforded compound 31a with a broad antibacterial spectrum against both Gram-positive and Gram-negative bacteria. Notably, it displayed a two-fold more active inhibition (MIC $=8 \mu \mathrm{g} / \mathrm{mL}$ ) than the reference drug chloromycin (MIC $=16 \mu \mathrm{g} / \mathrm{mL}$ ) against Proteus vulgaris ATCC 6896 as well as a similar antibacterial efficacy against S. aureus ATCC 25923 and Micrococcus luteus ATCC 4698 to chloromycin. When the two-carbon alkyl chain of this compound was changed into a three-carbon one, the antibacterial activity was not affected. However, compounds with four-carbon or longer alkyl chains possessed decreased bacterial inhibitory. The replacement of the alkyl chain in compound 31a by benzene containing aryl chain yielded another coumarin benzotriazole derivative $31 \mathrm{~b}$, which showed a less antibacterial activity than compound 31a. Furthermore, the results of synergistic effects showed that the combination use of compound 31a and fluconazole together could effectively inhibit the growth of C. albicans, S. cerevisiae and A. fumigatus with a MIC value of $0.25 \mu \mathrm{g} / \mathrm{mL}$ which was 8 or 4 folds higher than that of compound 31a alone [106,107]. The conjugate structure of coumarin and the substitution of benzotriazole can drastically enhance the antibacterial property, therefore this kind of compounds are worthy to be investigated in-depth.<smiles>Cc1cc(=O)oc2cc(OCCn3nnc4ccccc43)ccc12</smiles><smiles>Cc1cc(=O)oc2cc(OCc3ccccc3Cn3nnc4ccccc43)ccc12</smiles>

Several researches reported that the introduction of hydrophilic groups like amino group could not only easily form hydrogen bonds, but also readily accept protons to form quaternary salts possibly improving water solubility, or coordinate with metal ions activities [108]. Benzotriazole derivative 32 exhibited better inhibition against B. subtilis than the standard drug ampicillin [109]. The exchange of the amino group into methyl or methoxy group reduced its antibacterial activity, which indicated the valuable function of amino moiety in enhancing the antibacterial efficiency.<smiles>NC(c1ccc([N+](=O)[O-])cc1)n1nnc2ccccc21</smiles>

Thiazolidinones have exhibited a considerable pharmacological importance with antibacterial, antifungal, antitubercular, antiinflammatory and anticancer activities. The combination of thiazolidinone, benzotriazole and halogen-substituted benzene gave compounds $33 \mathrm{a}-\mathrm{c}$ with good antibacterial activity against Grampositive bacterium $S$. aureus and Gram-negative bacterium $E$. coli with MIC values ranging from 0.1 to $0.5 \mu \mathrm{g} / \mathrm{mL}$ in comparison to that of reference drug oflaxacin $(\mathrm{MIC}=0.1 \mu \mathrm{g} / \mathrm{mL})$ [110]. The replacement of the substituted benzene ring by an unsubstituted one would highly decrease the antibacterial activity, and this suggested that the electron withdrawing groups on the benzene ring were helpful to improve the bacterial inhibitory.<smiles>[R]c1ccccc1C1SCC(=O)C1NCCCn1nnc2ccccc21</smiles>

The combination of triazole and benzotriazole into one molecule 
yielded compound 34 with comparable antibacterial activity (MIC=1.56-6.25 $\mu \mathrm{g} / \mathrm{mL}$ ) against three Gram-positive bacterial strains (Bacillus subtilis, Staphylococcus aureus and Streptococcus faecalis) and three Gram-negative bacterial strains (Escherichia coli, Pseudomonas aeruginosa and Enterobacter cloacae) to that of the reference drugs kanamycin and penicillin [111]. The replacement of the 4-bromo group on the benzene ring by 2 -methyl group reduced its anti- $B$. subtilis activity. This result indicated that the introduction of bromo group may increase the hydrophobicity of the synthesized compounds, and lead to an enhanced antibacterial activity.<smiles>O=C(c1ccc(Br)cc1)C(Cn1nnc2ccccc21)n1cncn1</smiles>

$\mathrm{N}$-Alkylated benzotriazoles as the precursors in many organic syntheses and the fertile sources of medicinal agents are important antibacterial frameworks. Introduction of biphenyl and benzyl halides in $N$-alkyl benzotriazoles yielded derivatives $35 \mathrm{a}$ and $35 \mathrm{~b}$ via conventional and microwave irradiation technique with a 2-fold increased antibacterial activity (MIC=5.62-12.53 $\mu \mathrm{g} / \mathrm{mL}$ ) in comparison with standard drugs streptomycin and tetracycline against susceptible and resistant Gram-positive and Gram-negative microorganisms [112]. Enhancement of the inhibitory might be attributed to the presence of pharmaceutically important benzotriazole ring as well as biphenyl moiety.

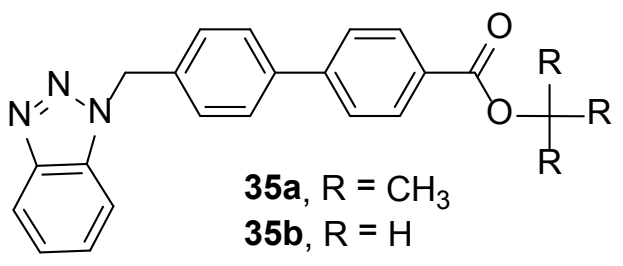

Acridine ring is an ideal framework in the medical field with various significant bioactivities including antibacterial, antimalarial, anticancer ability and so on. The combination of acridine with other functional groups tends to be an effective method to produce novel bioactive compound to overcome microbial resistance. Benzotriazole substituted acridine derivatives $36 \mathrm{a}$ and $36 \mathrm{~b}$ possessed comparable in vitro antibacterial potency against $S$. aureus, B. subtilis and E. coli to the reference drug ampicillin. It was worthy to note that the introduction of benzotriazole as well as the methyl or methoxyl group at C-2 position of the acridine ring efficiently improved the antibacterial activity [113].<smiles>[R]C(=O)[R15]1nc2ccccc2n1-c1c2ccccc2nc2ccc([R])cc12</smiles>

Arylazopyrazole derivatives are an important class of compounds in drug discovery due to their broad pharmacological activities. So far, the merged molecules of arylazopyrazole and benzotriazole have not been developed, although both of them possess good biological activities. In view of this, a series of arylazopyrazole substituted benzotriazoles were designed and synthesized. Among them, compound 37 exhibited comparable antibacterial activity to the reference sulphonamide against various bacteria including Gram-positive bacteria (Bacilus subtilis and Staphyllococcus aureus) and Gram-negative bacteria (E. coil, Salmonella typhi and Klebsiella promioe) [114]. The replacement of 2,3-dichlorophenyl group in compound 37 by unsubstituted benzene ring reduced the antibacterial activity. The two chlorine atoms of this compound were favorable for the bioactivities.<smiles>CC1=NN(C(=O)c2ccc(NCn3nnc4ccccc43)cc2)C(=O)/C1=N/Nc1cccc(S(=O)(=O)N2CCN(c3cccc(Cl)c3Cl)CC2)c1</smiles>

$s$-Triazine derivatives with anticancer, antiviral and antifungal activities have been attracting increasingly attention. Benzotriazole substituted 2,4,6-trichloro-s-triazine derivative 38 exhibited significant inhibition against Gram-negative bacteria E. coli and Gram-positive bacteria $S$. aureus with MIC values of 10 and $15 \mu \mathrm{g} / \mathrm{mL}$, respectively, which were both two-fold of the standard chloramphenicol [115]. It can be seen that the combination of aryl urea, benzotriazole and benzimidazole moieties was beneficial for the enhancement of antibacterial activity by providing sufficient electronic pressure and creating structurally crowding and various allosteric sites.<smiles>O=C(Nc1nc(-n2cnc3ccccc32)nc(-n2nnc3ccccc32)n1)Nc1ccccc1Cl</smiles>

Piperidine derivatives have exhibited wide applications in medicinal chemistry including as antifungal agents, hypoglycemic drugs, $\mathrm{K}^{+}$ion channel blockers, acetyl cholinesterase inhibitors and opioid receptor antagonists. The combination of piperidine and benzotriazole afforded newly structural N,N-dimethyl oxamide benzotriazole 39 with the advantages of low toxicity, high oral bioavailability and broad antibacterial spectra, especially it showed stronger inhibition than the standard streptomycin against $B$. pumilis and Entero. Aerogens [116]. Moreover, another benzotriazole-based piperidine derivative 40 showed two-fold inhibition (MIC $=6.25 \mu \mathrm{g} /$ $\mathrm{mL}$ ) against $B$. subtils (ATCC-530) in contrast with the standard drug streptomycin $(\mathrm{MIC}=12.5 \mu \mathrm{g} / \mathrm{mL})$ [117]. When its fluorine atom at 4 -position on benzene ring was changed into methoxy group, the antibacterial activity decreased, which indicated the importance of fluoro-benzene to the antibacterial efficiency.<smiles>CN(C)C(=O)C(=O)N1CCC(n2nc3ccccc3n2)CC1</smiles> 
<smiles>CCC1C(=O)C(CC)C(c2ccc(F)cc2)N(C(=O)Cn2nnc3ccccc32)C1c1ccc(F)cc1</smiles>

The newly synthesized arylazopyrazole-benzotriazole derivative 41 was reported to have comparable antibacterial ability to reference drug tetracycline against several tested strains such as Bacillus subtilis, Staphylo coccus aureus and E. coil [118]. The replacement of bromobenzene in this compound by chlorobenzene did not affect the antibacterial activity, however, when the bromobenzene was changed into methyl substituted benzene or unsubstituted benzene ring, the inhibitory efficiency decreased. The halogens in the benzene ring may contribute to the antibacterial activity.<smiles>CC1=NN(C(=O)c2ccc(NCn3nnc4ccccc43)cc2)C(=O)/C1=N/Nc1ccc(Br)cc1</smiles>

\section{Benzotriazole-containing metal complexes as antibacterial agents}

Ruthenium complexes are endowed to exhibit high rate of ligand exchanges, accessible oxidation states and the ability to bind with certain biological molecules. Benzotriazole containing ruthenium (III) complex 42 was found to be much more efficient against Gramnegative Escherichia coli in comparison to 1,2,3-benzotriazole ligand and precursor ruthenium compounds [119]. The increased lipophilicity of this complex reduced the permeability barriers of the cells and retarded the normal cell process of bacteria, thus resulting in enhanced antibacterial activity (Figure 7). Additionally, their positive reactivity and inherent bioactivity may throw a new light on the future of benzotriazole-based ruthenium (III) complexes as supramolecular agents.<smiles></smiles>

Novel $\mathrm{Cu}(\mathrm{II})$ complex of benzotriazole-based benzoic acid $\mathbf{4 3}$ exerted moderate inhibitions against both Gram-positive bacteria (Bacillus subtills and Staphylococcus aureus) and Gram-negative bacteria (Escherichia coli and Salmonella typhi) [120], which were also much better than that of complexes with other transition metal ions. The variation in structure on coordination of this complex may affect the growth of microorganisms, then resulting in increased bioactivity or reduced toxicology of metal ions towards some organisms.

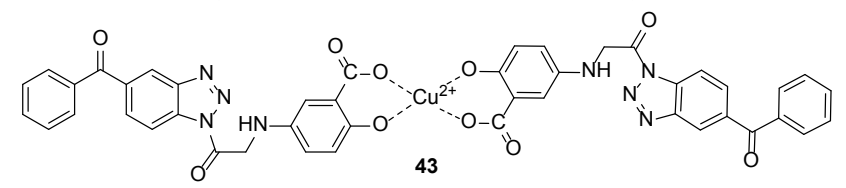

Benzotriazole-containing metal complexes have exerted their great potentiality as medicinal agents, not only for the excellent activity against bacterial or fungal strains, but also for the preliminary efficacy towards oxidative stress and cancer cell lines. These inspiring outcomings will attract more and more researchers to investigate benzotriazole-based metal complexes as medicinal agents against other diseases and make benzotriazole chemistry present a firenew prospect.

\section{Antitubercular Benzotriazoles}

Tuberculosis (TB) is a highly infectious disease primarily caused by Mycobacterium tuberculosis. Several types of antitubercular agents such as isoniazide and rifampicin are available for clinic. However, with the frequent occurrence of resistant strains and clinical adverse drug reactions of stomach and gut as well as liver damage, the uses of clinical anti-TB drugs have been limited by the reduced efficacy and inevitable toxic side effects (Figure 8). Therefore, there is necessary to develop new potent anti-tubercular drugs without cross resistance from known antimycobacterial agents. One of the most effective strategies to overcome this problem is to exploit the potentiality of standard short course chemotherapy based on cheap and safe first line drugs. Recently, more and more researches have shown that the nitrogen heterocyclic benzotriazole compounds have considerable potentiality to treat tuberculosis.

The substitution of benzotriazole ring by halogen atoms on the benzene ring has been proved to be a useful way to enhance the bioactivity of benzotriazole derivatives. Chlorine substituted benzotriazole derivative 44 exerted a considerable inhibition (MIC $=12.5$ $\mathrm{g} / \mathrm{mL}$ ) against isoniazidee-resistant $M$. tuberculosis 1753 [121]. It is worthy to note that when the chlorine atoms on the benzotriazole ring were replaced by other halogen atoms, the anti-mycobacterial activity markedly decreased. The nitro-substitution in the benzyloxy part of the molecule and the dichloro substituted benzotriazole resulted in its high biological activity.<smiles>O=[N+]([O-])c1cc(On2nnc3cc(Cl)c(Cl)cc32)cc([N+](=O)[O-])c1</smiles>

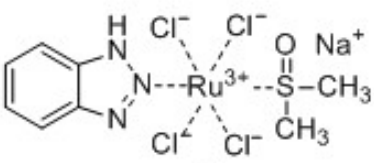

42<smiles>O=C(c1ccccc1)c1ccc2c(c1)nnn2C(=O)CNc1ccc2c(c1)C(=O)O[CH]O2</smiles>

Figure 7: Benzotriazole-Containing Metal Complexes as Antibacterial Agents. 
<smiles>O=[N+]([O-])c1cc(On2nnc3cc(Cl)c(Cl)cc32)cc([N+](=O)[O-])c1</smiles><smiles>O=S(=O)([Sb])Cn1nnc2ccccc21</smiles><smiles>O=C(NCCCn1nnc2ccccc21)N1C(=O)C(Cl)C1c1ccc(Br)cc1</smiles><smiles>O=C(C(Nc1ccccc1)n1nnc2ccccc21)n1nnc2ccccc21</smiles>

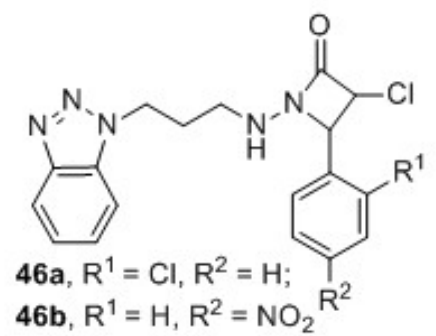<smiles></smiles>

Figure 8: Antitubercular Benzotriazoles.

Quinoxaline derivatives could prevent the synthesis of DNAdirected RNA by binding to CpG site on DNA. Herein, benzotriazolebased quinoxaline 45 was synthesized by acid-catalyzed Mannich condensation, and it possessed moderate inhibitory (MIC $=10.775 \mu \mathrm{g} /$ $\mathrm{mL}$ ) against $M$. tuberculosis $H_{37} R v$ [122]. The substitution on the cyclic nitrogen of quinoxaline by benzotriazole played an important role in the antitubercular activities of the parent pharmacophore.<smiles>[R5]S(=O)(=O)n1nnc2ccccc21</smiles>

Azetidinones are well known as $\beta$-lactams, they serve as synthones for many biologically important compounds with a broad range of biological activities. In order to develop novel and effective anti-TB agents, a series of benzotriazole containing aryl-azetidinones were designed and synthesized by conventional and microwave irradiation which was an attractive method offering little pollution, low cost and high yields together with simplicity in processing and handling. The antimicrobial screening results indicated that compounds $46 \mathrm{a}$ and $46 \mathrm{~b}$ displayed better inhibitions against $M$. tuberculosis with MIC values of 3.125 and $1.56 \mu \mathrm{g} / \mathrm{mL}$, respectively, in comparison to reference drug streptomycin $(\mathrm{MIC}=4 \mu \mathrm{g} / \mathrm{mL})$ [123]. Moreover, the combination of 2-oxoazetidine and benzotriazole afforded compound 47, which also exhibited potent in vitro antitubercular activity against $M$. tuberculosis $H 37 R v$ strain in comparison to reference drugs isoniazide and rifampicin [124]. The electron withdrawing substituents such as $\mathrm{NO}_{2}, \mathrm{Cl}$ and $\mathrm{Br}$ in benzene ring may contribute to their enhanced antitubercular activity.

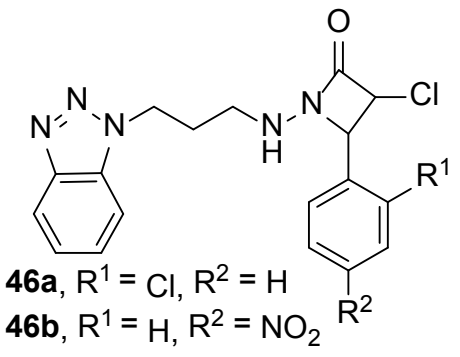<smiles>O=C(NCCCn1nnc2ccccc21)N1C(=O)C(Cl)C1c1ccc(Br)cc1</smiles>

Sydnones have drawn increasing attention in the fields of both heterocyclic chemistry and medicinal chemistry due to their structural features and biological activities. Some amide benzotriazole derivatives synthesized from sydnone fragment were reported to display good antitubercular activities. For instance, amino benzotriazole 48 was manifested to be a potent antitubercular agent with better inhibition $(\mathrm{MIC}=4.5 \mu \mathrm{g} / \mathrm{mL})$ against $M$. tuberculosis than standard drugs streptomycin $(\mathrm{MIC}=7.5 \mu \mathrm{g} / \mathrm{mL})$ and pyrazinamide $(\mathrm{MIC}=10 \mu \mathrm{g} / \mathrm{mL})$ [125]. The replacement of the phenyl ring in this molecule by $p$-tolyl or $p$-bromophenyl group slightly decreased its inhibitory activity.<smiles>O=C(C(Nc1ccccc1)n1nnc2ccccc21)n1nnc2ccccc21</smiles>

Pyrazole N-aryl derivatives have been deeply investigated in the pharmaceutical field due to their wide range of bioactivities such as anti-hyperglycemic, analgesic, antiinflammatory, antipyretic and antibacterial activities. The introduction of pyrazole ring in molecules could increase the electron density of the system and makes the chromophore more resistant towards enzymatic reduction by radical species. Herein, Mannich base reacted with the sydnone moiety gave novel biodynamic pyrazole containing benzotriazole derivative 49 with a moderate antitubercular inhibition $(\mathrm{MIC}=12 \mathrm{~g} / \mathrm{mL})$ against $M$. tuberculosis $(\mathrm{H} 37 \mathrm{Rv})$ in comparison to standard drug pyrazinamide $(\mathrm{MIC}=10 \mathrm{~g} / \mathrm{mL}$ ) [126]. The encouraging activity of this compound could be attributed to the presence of benzotriazole ring and electron donating groups like hydroxyl, amino and methylene groups through mesomeric effect appended to the pyrazole moiety. 
<smiles></smiles>

\section{Antiviral Benzotriazoles}

Virus is a class of infinitesimal pathogen. Viral infections cause about $60 \%$ of epidemic infectious diseases and seriously threaten to human health. Traditional nucleosides are prominent drugs used to treat viral infections. However, the structural modifications of nucleosides are faced with a major challenge because of poor solubility in common organic solvents [127]. Moreover, the current antiviral agents can not only inhibit the growth of virus instead of directly destroying and killing them, but also damage the host cell (Figure 9). For these reasons, large numbers of investigations have been focused on the design and development of non-nucleoside compounds as novel antiviral drugs in recent decades. The exploitation of new antiviral benzotriazole compounds has opened a new opportunity in this field.

Hepatitis $C$ is a liver disease caused by the hepatitis $C$ virus (HCV). HCV is a single-stranded positive RNA virus in the family of flaviviridae, which is associated with severe liver diseases including cirrhosis, liver cancer, and liver failure, and large numbers of people worldwide are chronically infected by this virus. Some novel aryl thiourea derivatives have been found to possess potent activity with nanomolar range in a cell-based HCV replicon assay. However, these compounds have significant cytotoxicity and poor pharmacokinetic activities. The newly synthesized thiourea benzotriazole derivative 50 could inhibit HCV subgenomic replication with a moderate efficiency $\left(\mathrm{IC}_{50}>50 \mu \mathrm{g} / \mathrm{mL}\right.$ ) [128]. Importantly, this compound showed lower cytotoxicity and better pharmacokinetic activities than previously synthesized aryl thiourea derivatives. Preliminary SAR study of this compound is currently under active investigation.<smiles>NC(=S)Nc1ccc2nn[nH]c2c1</smiles>

A lot of benzimidazole substituted benzotriazoles have been found to have antiviral abilities. For example, compound 51 exhibited a significant antiviral effect on Respiratory Syncytial Virus (RSV) with an $\mathrm{EC}_{50}$ value of $0.1 \mu \mathrm{g} / \mathrm{mL}$, which was more effective than the reference drug azauridine $\left(\mathrm{EC}_{50}=1.2 \mu \mathrm{g} / \mathrm{mL}\right)$ [129]. It was proved to be a potent RSV inhibitor. The presence of benzotriazole might reduce the cytotoxicity and contribute to its high selectivity index.<smiles>CCN(CC)CCn1c(Cn2nnc3ccccc32)nc2cc(Cl)ccc21</smiles>

The persistent infection with hepatitis $\mathrm{B}$ virus (HBV) remains a seriously global healthy problem. However, the clinical available nucleoside analogues can lead to low response rate in the patient and result in the development of drug-resistant virus after long-term treatment, so this condition promotes to explore novel non-nucleoside antiviral drugs with excellent inhibitory activity on the replication of HBV DNA and the secretion of $\mathrm{HBV}$ e antigen (HBeAg) and HBV surface antigen (HBsAg). The development of new anti-HBV agents is focused on discovering diverse compounds with either novel structures or a new mechanism of action. The new structural benzotriazole derivative 52 displayed significant ability in reducing the secretion of $\mathrm{HBsAg}$ and $\mathrm{HBeAg}$ with better $\mathrm{IC}_{50}$ values of 33.7 and $111.4 \mu \mathrm{g} / \mathrm{mL}$, respectively, than clinic antiviral drug tenofovir $\left(\mathrm{IC}_{50}=1450.1\right.$ and $1160.2 \mu \mathrm{g} / \mathrm{mL}$ ), and its selective index (SI) was higher than that of tenofovir. Furthermore, compound 52 could effectively reduce the DNA replication of $\mathrm{HBV}\left(\mathrm{IC}_{50}=8.3 \mu \mathrm{g} / \mathrm{mL}\right)$. The research manifested that this compound represented a potent new structural non-nucleoside drug candidate for the treatment of HBV infections. For the C-2 substituted quinoline benzotriazole derivatives, the size and character of the substituents largely affect their anti-HBV activities [130].<smiles>O=S(=O)(O)c1nc2ccc(Cl)cc2c(-c2ccccc2Cl)c1CCO</smiles><smiles>NC(=S)Nc1ccc2nn[nH]c2c1</smiles>
50<smiles>CCN(CC)CCn1nnc2ccccc21</smiles><smiles>O=S(=O)(O)c1cc(-c2ccccc2Cl)c(CCO)c(Nn2nnc3ccccc32)n1</smiles><smiles>O=c1c2ccccc2nc(-c2ccccc2)n1NCn1nnc2ccccc21</smiles><smiles>O=C(NC(CCN1CCC(O)(Cn2nnc3ccccc32)CC1)c1ccccc1)c1ccc(F)cc1</smiles>

Figure 9: Antiviral Benzotriazoles 
Since the first report in 1981, AIDS caused by HIV has become a widespread disease. Although highly active antiretroviral therapy can effectively suppress the load of HIV and decrease the mortality in AIDS patients, the emergence of drug resistance, the unavoidable viral recurrence after drug treatments and the toxicity of the therapy make it necessary to continuously search for novel anti-HIV drugs [131].

Quinazoline derivatives are an attractive kind of pharmacological scaffolds present in many potent marketed drugs. The structural modification of quinazolines can effectively accommodate the physicochemical activities and pharmacokinetics properties of drugs. Literature manifested that $4-(3 \mathrm{H})$-quinazoline is a versatile leading molecule for the design of potential antiviral agents, especially against HIV-1 (III ${ }_{\mathrm{B}}$ ) and HIV-2 (ROD) in MT-4 cells. A series of novel 2 phenyl3substituted $4-(3 \mathrm{H})$-quinazolines were synthesized and nearly all the tested compounds displayed significant cytostatic properties in the antiviral evaluation. Noticeably, the benzotriazole substituted quinazoline derivative 53 showed better antiviral activity against III $_{B}$ $\left(\mathrm{CC}_{50}=61.33 \mu \mathrm{g} / \mathrm{mL}\right)$ than standard drug AZT $\left(\mathrm{CC}_{50}=72.00 \mu \mathrm{g} / \mathrm{mL}\right)$ [132]. This compound also had good cytotoxic effect against other viruses like HSV-I, HSV-II, Para influenza-3, Coxsackie virus $\mathrm{B}_{4}$ and Punta Toro virus.<smiles>O=c1c2ccccc2nc(-c2ccccc2)n1NCn1nnc2ccccc21</smiles>

The expression of chemokine receptor CCR5 would make cells infected with macrophage-tropic (R5) HIV-1 strains. The blockade of the CCR5 receptor could not only treat HIV-1 infections but also reduce many mechanism-related side effects. These facts have inspired much effort to identify new CCR5 antagonists. Piperidin-4-hydroxyl benzotriazole derivative 54 possessed comparable CCR5 antagonistic activity with a promising $\mathrm{IC}_{50}$ value of $1.28 \mu \mathrm{g} / \mathrm{mL}$ [133]. The nitrogen atoms of benzotriazole in compound 54 could be considered to anchor the ligands to the CCR5 receptor via a strong salt-bridge interaction, and its lipophilic group could be another common feature of most CCR5 antagonists.<smiles>CC(C)(C)OC(=O)c1ccc(F)cc1C(=O)NC(CCN1CCC(O)(Cn2nnc3ccccc32)CC1)c1ccccc1</smiles><smiles>Clc1ccc2[nH]nnc2c1</smiles>

55

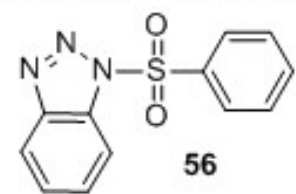

\section{Antiparasitic Benzotriazoles}

Parasitosis is a kind of epidemic diseases causing serious damages to both society and economy. This disease is associated with infectious parasite present multiformity, including helminthiasis and protozoiasis etc. The threats of parasites on public health, inadequacy of current treatments and drug resistance have created an urgent requirement for more effective drugs. Several benzotriazole derivatives with advanced antiparasitic activity have showed potentiality to solve this problem $[134,135]$.

Amebiosis, caused by the protozoan parasite Entamoeba histolytica (E. histolytica), is responsible for large numbers of deaths and many people infected with E. histolytica. However, there are still $90 \%$ of patients remain asymptomatic while carrying the infection for several years, estimated by WHO. The clinical drugs such as azomycin are faced with parasite resistance and negative side effects (Figure 10). In order to investigate the novel compounds with effective, benzotriazole derivative 55 was obtained and possessed low micromolar activity $\left(\mathrm{IC}_{50}=0.339 \mu \mathrm{g} / \mathrm{mL}\right.$ ), which was more active than metronidazole, the clinical choice for the treatment of amebiosis 641 [136]. When the chlorine atom in compound 55 was changed into methyl group, the antiprotozoan activity greatly decreased $\left(\mathrm{IC}_{50}=3.248 \mu \mathrm{g} / \mathrm{mL}\right.$ ). These results indicate that the benzotriazole scaffold represents an excellent starting point for an optimization of novel antiparasite drugs.<smiles>Clc1ccc2[nH]nnc2c1</smiles>

Chagas disease, caused by the protozoan Trypanosoma cruzi, is considered to be a major infectious heart disease in Central and South America, and is recognized as one of the world's thirteen most neglected tropical diseases by WHO. The only available drugs for specific treatment of this disease are the nitrofuran derivatives, nifurtimox and 2-nitroimidazole benznidazole (BZL). However, all of them have significant activities only in the acute or recent chronic form of the disease. The development of novel, safe and effective trypanocidal compounds is still in necessary need. The newly synthesized N-benzenesulfonyl benzotriazole 56 showed good inhibitory activity $\left(\mathrm{IC}_{50=} 21.56 \mu \mathrm{g} / \mathrm{mL}\right)$ against epimastigotes of Trypanosoma cruzian, whereas the standard benzotriazole exhibited no inhibitory on the growth of this parasite form [137]. These results revealed the potentiality of compound 56 as a prototype in drug design for developing new anti-T. cruzi agents.<smiles>O=S(=O)(c1ccccc1)c1ccccc1</smiles><smiles>[R][R6]#[Sb]</smiles>

Figure 10: Antiparasite Benzotriazoles. 
Filarial parasite is still a big medicinal problem and so far there is no safe and effective drug that is available to combat adult human filarial worms, because they have a very strong antioxidant system, which could protect them from the reactive oxygen species (ROS) produced by the normal metabolism or by immune cells of the hostis. The research and development of antifilarial drugs have drawn increasing attention. Chalcones as an important group of natural product, are the precursors of various flavones and exhibit a wide spectra of biological significance such as antimicrobial, antibacterial, antitumor and antimalarial activities [138-140]. The combination of chalcone with benzotriazole gave compound 57a, which showed a significant suppression in antifilarial activity on Setaria cervi using glutathione-S-transferase (GST) as a drug target against adult female parasite at a concentration of $3 \mu \mathrm{g} / \mathrm{mL}$. Further evaluations demonstrated that this compound exhibited major irreversible effects on bioactivity, then resulted in the death of parasite and also inhibited the GST activity with the percentage of $84-100 \%$ in vitro [141]. In addition, when its methoxy group was replaced by chlorine, another chalcone benzotriazole derivative $57 \mathrm{~b}$ was yielded, which displayed superior potentiality to treat the common disease malaria caused by Plasmodium falciparum $\left(\mathrm{IC}_{50}=2.5 \mu \mathrm{g} / \mathrm{mL}\right)$ [142]. Structure-activity relationship manifested that the introduction of benzotriazole into methoxy or chlorine substituted chalcone played an influential role in the antiparasitic potency.<smiles>[R]C(=O)[R6]#[R5]</smiles>

\section{Antioxidative Benzotriazoles}

Free radicals, represented by reactive oxygen nitrogen species from human metabolism, could produce harmful substances by a variety of metabolic pathways, then cause healthy problems, such as aging, cancer and many neurodegenerative diseases (Figure 11). Therefore, eliminating the excessive oxidized free radicals, improving the antioxidative activities of the body to resolve the aging-related diseases has been an increasingly important challenge. Antioxidants are reducing agents used to stabilize some free radicals produced by cellular metabolism [143]. Benzotriazole compounds have shown remarkable antioxidative activities and large potentiality to be novel antioxidative agents or candidates.

Primaquine (PQ) derivatives are well-known and wide-used antimalarial drugs, meanwhile they are interesting molecules to develop potential antioxidative agents due to their prooxidant effects in blood. Benzotriazole substituted primaquine 58 showed a higher interaction $(73.8 \%)$ than the parent compound primaquine $(31 \%)$, and it also exhibited a good lipoxygenase inhibitory (LOX) inhibition $\left(\mathrm{IC}_{50}=260 \mu \mathrm{g} / \mathrm{mL}\right)$ [144]. In addition, benzotriazole derivative $59 \mathrm{had}$ perfect DPPH interaction value (85\%), which was comparable to that of the reference compound nordihydroguaiaretic acid (91\%) at the same concentration. This compound also displayed a good lipid peroxidation (LP) inhibition of $31 \%$ [145]. These results proved the promising efficiency of the benzotriazole group as a new scaffold in the rational design of new antioxidant compounds.<smiles>COc1cc(NC(C)CCCNn2nnc3ccccc32)c2ncccc2c1</smiles><smiles>O=C(NNC(=O)n1nnc2ccccc21)NOCc1ccccc1</smiles>

Ketoprofen (Ket) is a non-steroidal antiinflammatory drug (NSAID) with pronounced analgesic and antipyretic activities. Recently, the structural modification of ketoprofen molecule has afforded a series of derivatives with minimized side-effects, prolonged plasma halflife, increased solubility and considerable antioxidative potentiality. For example, ketoprofen benzotriazole derivative 60 possessed good interaction with 1,1-dipheny 1-2-picrylhydrazyl (DPPH) which was a stable free radical with spared electron delocalization over the whole molecule. The interaction between compound 60 and DPPH indicated its radical scavenging ability in an iron-free system as well as its reducing activity. Moreover, it was proved to be an excellent inhibitor of LP of $98 \%$, which was significantly higher than that of the standard drug ketoprofen (69.3\%). This compound also exhibited remarkable soybean LOX activity of $95 \%$ [146]. The replacement of benzotriazole ring by other substituent such as pyrrolyl or piperidyl fragment could obviously reduce the antioxidant activity, which indicated that the presence of benzotriazole was benifical to its antioxidant propiety.<smiles>CC(C(=O)n1nnc2ccccc21)c1cccc(C(OC(=O)n2nnc3ccccc32)c2ccccc2)c1</smiles>

\section{Benzotriazole as Other Medicinal Agents}

Apart from the above mentions, benzotriazole compounds also<smiles>COc1cc(NC(C)CCCNn2nnc3ccccc32)c2ncccc2c1</smiles>

58

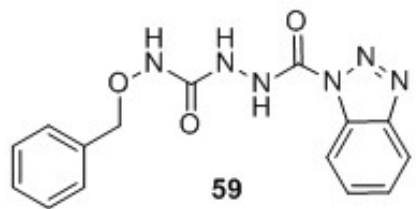<smiles>CC(C(=O)n1nnc2ccccc21)C(OC(=O)n1nnc2ccccc21)c1ccccc1</smiles>

Figure 11: Antioxidative Benzotriazoles. 
exhibited potential applications in other medical fields, including as antiinflammatory, antidiabetic agents, antimalarial agents and so on (Figure 12).

Inflammation is a complicated disease with a series of uncomfortable symptoms caused by tissue injury, infection of trauma or biochemical stimulation. Pain is one of the classic signs of the inflammatory process induced by different chemical mediators released during this process leading to nociceptive sensitization. A lot of nonsteroidal antiinflammatory drugs (NSAIDs) are available for the treatment of pain and inflammation. However, most of NSAIDs show limited antiinflammatory efficacy and cause various side effects such as gastrointestinal ulcers and hemorrhages. Therefore, much effort dedicates to exploit novel and effective NSAIDs. Recently, more and more literature indicated that benzotriazole derivatives have potentiality in the treatment of inflammations [147].

Cytosolic phospholipase $\mathrm{A}_{2} \alpha\left(\mathrm{CPLA}_{2} \alpha\right)$ is an attractive target for the design of new antiinflammatory drugs, since the inhibition of $\mathrm{CPLA}_{2} \alpha$ could lead to the blockade of cellular production of all these inflammatory lipid mediators. Benzotriazole-6-carboxylic acid 61 displayed good inhibition of $\mathrm{CPLA}_{2} \alpha\left(\mathrm{IC}_{50}=0.016 \mu \mathrm{mol} / \mathrm{L}\right)$. The replacement of carboxyl benzotriazole into carboxyl indole ring or carboxyl benzimidazole resulted in decreased inhibitory activities $\left(\mathrm{IC}_{50}=0.035\right.$ and $0.085 \mu \mathrm{mol} / \mathrm{L}$, respectively) [148]. These results suggested that the benzotriazole ring played an important role in enhancing its antiinflammatory ability.<smiles>O=C(COc1ccc([PH2+])cc1)Cn1nnc2ccc(C(=O)O)cc21</smiles>

61

Some researches manifested that the incorporation of sulfanilamide moiety into nitrogen-containing aromatic heterocycles could exhibit various or even enhanced pharmacological activities compared to the sulfanilamide precursor [149]. Moreover, four-nitrogen tetrazole ring is useful in the design of medicinal drugs with high bioactivity, and is frequently employed to develop new active molecules. Some tetrazole derivatives such as cephalosporins have been reported to possess antinociceptive, antiinflammatory, antimicrobial and anticonvulsant activities [150]. Tetrazole linked sulfanilamide benzotriazole derivative 62 displayed superior antiinflammatory efficiency compared to the standard drug paracetamol with an inhibitory percentage of $47 \%$ [151]. Further evaluation also confirmed that this compound had comparable anti-nociceptive activity to the standard drug pentazocine. The introduction of substituted sulfonyl moiety and benzotriazole may enhance the antiinflammatory property.<smiles>Nc1ccc(S(=O)(=O)n2nnc(CCn3nnc4ccccc43)n2)cc1</smiles>

The $c$-Jun $N$-terminal kinases (JNKs) are important members of mitogen-active protein kinase (MAPK) family, which are able to phosphorylate the $\mathrm{N}$-terminal transactivation domain of $c$-Jun, resulting in the enhancement of $c$-Jun dependent transcriptional events. Based upon the important role of JNK in the response of $T$ cell immune and regulating the expression or function of inflammatory cytokines (TNFa, IL-2, IL-6, etc.) that are central to many human inflammatory disorders, therefore, the inhibition of JNK may have potent therapeutic utilities. Pyrimidine is one of the most prominent structures found in nucleic acid, which is fundamental building block for deoxyribonucleic acid and ribonucleic acid. Pyrimidine derivatives play an essential role in several biological processes and in the pharmaceutical area, and even form a number of useful drugs. The amino derivatives have also been frequently reported to be talent inhibitors of JNKs. Pyrimidine containing morpholino-amide benzotriazole 63 gave good selectivity against JNK1 and JNK2 with $\mathrm{IC}_{50}$ values of 0.063 and $0.18 \mu \mathrm{mol} / \mathrm{L}$, respectively, versus cyclin-dependent kinase-2 $\left(\mathrm{IC}_{50}=2.0 \mu \mathrm{mol} / \mathrm{L}\right)$ [152]. Moreover, it maintained reasonable cell potencies greater than ten-fold cytotoxicity. This compound provided the rationale for further exploration of amide-substituted benzotriazole compounds as JNK inhibitors. So far, no successful JNK inhibitors have been used in clinic, but hopefully advanced compounds such as benzotriazole derivative 63 might be proved useful to inhibit many JNK enzymes.<smiles>O=C(COc1ccc([12F])cc1)Cn1nnc2ccc(C(=O)O)cc21</smiles>

61<smiles>O=C([C@H]1CC[C@H](Cc2nccc(-n3nnc4ccccc43)n2)CC1)N1CCOCC1</smiles><smiles>CC(C)C(=O)Nc1ccc2nn(-c3ccc(Cl)cc3)nc2c1</smiles><smiles>Nc1ccc(S(=O)(=O)n2nnc(CCn3nnc4ccccc43)n2)cc1</smiles><smiles>O=C(c1ccccc1)C(Cc1ccc2cc(Br)c(C(F)(F)P(=O)(O)O)cc2c1)(Cc1ccc2ccc(Br)c(C(F)(F)P(=O)(O)O)c2c1)n1nnc2ccccc21</smiles><smiles>O=C(Cn1nnc2ccccc21)N/N=C/c1ccc(Oc2ccc3c(c2)OCO3)cc1</smiles>

Figure 12: Benzotriazoles as Other Medicinal Agents. 
<smiles>O=C([C@H]1CC[C@H](Cc2nccc(-n3nnc4ccccc43)n2)CC1)N1CCOCC1</smiles>

Diabetes is a worldwide disease with an increasing and alarming incidence and large numbers of patients. Current treatments for diabetic patients include various oral antihyperglycemic agents, however, nearly half of type 2 diabetes mellitus (T2DM) sufferers lose their response to these agents after long term treatment, thus, there is an urgent need to develop novel agents for glycemic control that have good curable efficiency and could prevent the progression of secondary complications associated with diabetes. Recently, the inhibition of protein tyrosine phosphatase 1B (PTP1B) has been considered as one of the best validated biological targets for the treatment of T2DM, since it acts as a negative regulator in insulin signaling pathways and dephosphorylates key tyrosine residues within the regulatory domain of the subunit of the insulin receptor. Therefore, the inhibition of PTP1B activity may enhance the insulin action by prolonging the phosphorylated state of the insulin receptor. The introduction of the benzotriazole ring system into molecules as a base may rigidly lock the molecule into the active site and provided superior selectivity for PTP1B over other PTPs. Benzotriazole-based PTP1B inhibitor 64 showed remarkable anti-hyperglycemic effects in animal models, along with improved oral bioavailability, which also displayed high selectivity and improved inhibitory activity against PTP1B and T-cell protein tyrosine phosphatase (TCPTP) with $\mathrm{IC}_{50}$ values of 5 and $589 \mathrm{nmol} / \mathrm{L}$, respectively [153]. Further molecular docking analysis suggested that this compound could effectively bind with the active site of PTP1B (PDB code: 1Q6T), and these results were in agreement with the observed in vitro PTP1B selectivity. The highly potent and selective benzotriazolebased PTP1B inhibitors may represent an approach towards the safe and effective regulation of glucose homeostasis in T2DM patients.

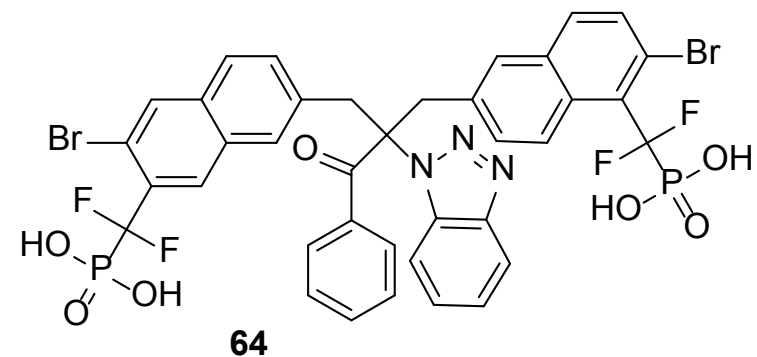

Duchenne muscular dystrophy (DMD) is a common, genetic neuromuscular disease associated with progressive deterioration of muscle function, which is mainly caused by being lack of the dystrophin protein. So far, the treatment of DMD is only symptomatic and it remains a pressing need for an effective therapy by novel agents. 2-Arylbenzotriazoles have been reported to possess positive effects in predictive screens of endogenous utrophin upregulation. Novel isopropylamide benzotriazole derivative 65 exhibited promising property to treat $\mathrm{DMD}\left(\mathrm{EC}_{50}=0.76 \mu \mathrm{g} / \mathrm{mL}\right)$ as well as moderate aqueous solubility [154]. The replacement of the isopropyl group in compound 65 by methyl or ethyl groups resulted in decreased bioactivities. Moreover, when the chlorine moiety at 4-postition on the benzene was changed into other position or substituted by other group ring, the efficiency also reduced. The structure activity relationship demonstrated that the introduction of isopropylamide and chlorobenzene moiety into benzotriazole ring made important contributions to the increased bioactivity. This compound has shown considerable potentiality to treat DMD and have already been progressed for in vivo evaluations.<smiles>CC(C)C(=O)Nc1ccc2nn(-c3ccc(Cl)cc3)nc2c1</smiles>

Epilepsy is a frequent neurological disease affecting more than 50 millions of people all around the world. The majority of clinical agents have certain disadvantages such as staggering cost treatment and dose-related side effects. In recent years, increasing attention has been paid to develop benzotriazole compounds as anticonvulsant drugs due to their unique structure related good activities and low toxicity. Benzotriazole substituted acetohydrazide 66 displayed significant activity with $75 \%$ protection $(3 / 4,0.5 \mathrm{~h})$ at a dose of $100 \mathrm{mg} / \mathrm{kg}$ in mice, importantly, it exhibited no neurotoxicity. Furthermore, it also exerted good binding properties with epilepsy molecular targets such as glutamate, GABA (A) delta, GABA (A) alpha-1 receptors and $\mathrm{Na} / \mathrm{H}$ exchanger in Lamarckian genetic algorithm based flexible docking studies [155]. These results indicated that benzotriazole analogs were promising as anticonvulsant agents and provided useful models for further structural optimization.<smiles>O=C(Cn1nnc2ccccc21)N/N=C/c1ccc(Oc2ccc3c(c2)OCO3)cc1</smiles>

\section{Conclusion}

As can be seen from the above mentions, benzotriazole-based compounds with various outstanding bioactivities have become increasingly active in the field of medicinal chemistry. Importantly, some anticancer benzotriazole compounds such as vorozole and TBB have been clinically used. It can be reasonable to expect that benzotriazole derivatives will play remarkable roles in medicinal field. Currently, the researches and developments of benzotriazole compounds have been focused on the following two main aspects:

On the one hand, an increasing effort is the structural modification by the introduction of benzotriazole ring into available drugs, and focused more on new struactrual benzotriazole-containing compounds with novel mechanisms of action. The electron-rich benzotriazole ring with a large conjugated system is an attracting molecular skeleton, which is not only easily modified by various types of functional groups, but also employed to combine with other bioactive fragments to afford more active compounds with remarkable physicochemical properties. However, simple introduction of other groups into benzotriazole skeleton or combination of benzotriazole ring with other pharmacophores is aimless and inefficient, thus rational design and high qualitative bioactive evaluation of novel types of benzotriazole leading compounds with completely new structures in modern methods such as computer-aided design and high throughput screening will become more and more important.

On the other hand, the design and developments of benzotriazolecontaining metal complexes will become an actively important direction. Three-nitrogen containing conjugated benzotriazole compounds with promising charge-transfer property are ready to form hydrogen bonds as well as cooperation bonds, therefore, they can coordinate with other metal ions or molecules through nitrogen atoms of benzotriazole or bind with other groups based on diffeerent 
Citation: Ren Y, Zhang L, Zhou CH, Geng RX (2014) Recent Development of Benzotriazole-based Medicinal Drugs. Med chem 4: 640-662. doi:10.4172/2161-0444.1000207

kinds of weak interactions, thus exhibiting promoted potentiality in the field of metal complexes as medicinal agents with reliable safety, low toxicity, few side effects, high bioavailability, strong target-directivity, weak multidrug-resistence, excellent biocompatibility and outstanding curative effects, etc.

Undoubtedly, with increasing effort directly towards bioactive benzotriazole compounds, a growing number of benzotriazole derivatives will inevitably be used in clinic and make remarkable contributions to human's health.

\section{Acknowledgements}

This work was partially supported by National Natural Science Foundation of China [No. 21172181, 21372186], the Key Program of Natural Science Foundation of Chongqing (CSTC2012jiB10026), the Specialized Research Fund for the Doctoral Program of Higher Education of China (SRFDP 20110182110007)

\section{References}

1. Peng XM, Cai GX, Zhou CH (2013) Recent developments in azole compounds as antibacterial and antifungal agents. Curr Top Med Chem 13: 1963-2010.

2. Zhou CH, Wang $Y$ (2012) Recent researches in triazole compounds as medicinal drugs. SCurr Med Chem 19: 239-280.

3. Wei JJ, Wang Y, Wang XL, Zhou CH, Ji QG (2011) Recent developments of 2,3-triazoles in medicinal chemistry. Chin Pharm J 46 481-485.

4. Pasqualotto AC, Thiele KO, Goldani LZ (2010) Novel triazole antifungal drugs: focus on isavuconazole, ravuconazole and albaconazole. Curr Opin Investig Drugs 11: 165-174.

5. Zhang L, Peng XM, Damu GL, Geng RX, Zhou CH (2014) Comprehensive review in current developments of imidazole-based medicinal chemistry. Med Res Rev 34: 340-437.

6. Cui SF, Wang Y, Lv JS, Damu GLV, Zhou CH (2012) Recent advances in application researches of thiazole compounds. Scientia Sinica Chimica 42: 1105-1131.

7. Zhang FF, Gan LL, Zhou CH (2010) Synthesis, antibacterial and antifungal activities of some carbazole derivatives. Bioorg Med Chem Lett 20: 1881-1884.

8. Zhou CH, Zhang FF (2011) Process for preparation of carbazole containing chalcone derivatives. CN Patent CN101993432 (A).

9. Zhang HZ, Zhou CH, Geng RX, Qing-Gang JI (2011) Recent advances in syntheses of oxazole compounds. Chin. J Org Chem 31: 1963-1976.

10. Zhang SL, Damu GL, Zhang L, Geng RX, Zhou CH (2012) Synthesis and biological evaluation of novel benzimidazole derivatives and their binding behavior with bovine serum albumin. Eur J Med Chem 55: 164-175.

11. Zhou CH, Yu KG, Meng J, Fang B, Luo Y, et al. (2009) Dibenzimidazole and onium compound thereof, preparation method and medical use thereof.

12. Suma BV, Natesh NN, Madhavan V (2011) Benzotriazole in medicinal chemistry: an overview. J Chem Pharm Res 3: 375-381.

13. Loi CH, Busetti F, Linge KL, Joll CA (2013) Development of a solid-phase extraction liquid chromatography tandem mass spectrometry method for benzotriazoles and benzothiazoles in wastewater and recycled water. J Chromatogr A 1299: 48-57.

14. Liu YS, Ying GG, Shareef A, Kookana RS (2013) Biodegradation of three selected benzotriazoles in aquifer materials under aerobic and anaerobic conditions. J Contam Hydrol 151: 131-139.

15. Wang L, Zhao L, Xue RY, Lu XF, Wen YH, et al. (2012) Construction of interesting organic supramolecular structures with synthons cooperation in the cocrystals of $1 \mathrm{H}$-benzotriazole and hydroxybenzoic acids. Sci China Chem 55: 2515-2522.

16. Piccionello AP, Guarcello A (2010) Bioactive compounds containing benzoxadiazole, benzothiadiazole, benzotriazole. Curr Bioact Compd 6: 266283.

17. Singh G, Kumar R, Swett J, Zajc B (2013) Modular synthesis of N-vinyl benzotriazoles. Org Lett 15: 4086-4089.

18. Milosevic NP, Dimova VB, Perisic-Janjic NU (2013) RP TLC data in correlation studies with in silico pharmacokinetic properties of benzimidazole and benztriazole derivatives. Eur J Pharm Sci 49: 10-17.
19. Kattimani PP, Kamble RR, Kariduraganavar MY, Dorababu A, Hunnur RK (2013) Synthesis, characterization and in vitro anticancer evaluation of novel, 2,4-triazolin-3-one derivatives. Eur J Med Chem 62: 232-240.

20. Zhou CH, Zhang FF, Gan LL, Zhang YY, Geng RX (2009) Research in supermolecular chemical drugs. Sci China Ser B: Chem 39: 208-252.

21. Tang YD, Zhang JQ, Zhang SL, Geng RX, Zhou CH (2012) Synthesis and characterization of thiophene-derived amido bis-nitrogen mustard and its antimicrobial and anticancer activities. Chin J Chem 30: 1831-1840.

22. Duncan JS, Gyenis L, Lenehan J, Bretner M, Graves LM, et al. (2008) An unbiased evaluation of CK2 inhibitors by chemoproteomics: characterization of inhibitor effects on CK2 and identification of novel inhibitor targets. Mol Cell Proteomics 7: 1077-1088.

23. Entezar M, Safari M, Hekmati M, Hekmat S, Azin A (2014) Modification of carboxylated multiwall nanotubes with benzotriazole derivatives and study of their anticancer activities. Med Chem Res 23: 487-495.

24. Yuan J, Zhong Y, Li SL, Zhao X, Luan GQ, et al. (2013) Triazole and benzotriazole derivatives as novel inhibitors for p90 ribosomal S6 protein kinase 2: synthesis, molecular docking and SAR analysis. Chin J Chem 31: 1192-1198.

25. Cheng X, Merz KH, Vatter S, Christ J, Wolfl S, et al. (2014) 7,7'-Diazaindirubin-a small molecule inhibitor of casein kinase 2 in vitro and in cells. Bioorg Med Chem 22: 247-255.

26. Pagano MA, Bain J, Kazimierczuk Z, Sarno S, Ruzzene M, et al. (2008) The selectivity of inhibitors of protein kinase CK2: an update. Biochem J 415: 353365.

27. Gyenis L, Turowec JP, Bretner M, Litchfield DW (2013) Chemical proteomics and functional proteomics strategies for protein kinase inhibitor validation and protein kinase substrate identification: applications to protein kinase CK2. Biochim Biophys Acta 1834: 1352-1358.

28. Najda-Bernatowicz A, $\AA$ ebska M, Orzeszko A, Kopa $\AA$, ska K, Krzywi „,ska E et al. (2009) Synthesis of new analogs of benzotriazole, benzimidazole and phthalimide--potential inhibitors of human protein kinase CK2. Bioorg Med Chem 17: 1573-1578.

29. Wawro AM, Wielechowska M, Bretner M (2013) Synthesis of new optically pure tetrabromobenzotriazole derivatives via lipase-catalyzed transesterification. J Mol Catal B: Enzym 87: 44-50.

30. Janeczko M, Maslyk M, Szyszka R, Baier A (2011) Interactions between subunits of protein kinase CK2 and their protein substrates influences its sensitivity to specific inhibitors. Mol Cell Biochem 356: 121-126.

31. Bretner M, Najda-Bernatowicz A, Lebska M, Muszynska G, Kilanowicz A, et al (2008) New inhibitors of protein kinase CK2, analogues of benzimidazole and benzotriazole. Mol Cell Biochem 316: 87-89.

32. Gyenis L, Kus A, Bretner M, Litchfield DW (2013) Functional proteomics strategy for validation of protein kinase inhibitors reveals new targets for a TBBderived inhibitor of protein kinase CK2. J Proteomics 81: 70-79.

33. Makowska M, Lukowska-Chojnacka E, Winska P, Kus A, Bilinska-Chomik A et al. (2011) Design and synthesis of CK2 inhibitors. Mol Cell Biochem 356 91-96.

34. Huang X, Cheng CC, Fischmann TO, Duca JS, Richards M, et al. (2013) Structure-based design and optimization of 2-aminothiazole-4-carboxamide as a new class of CHK1 inhibitors. Bioorg Med Chem Lett 23: 2590-2594.

35. Fu J, Yang Y, Zhang XW, Mao WJ, Zhang ZM, et al. (2010) Discovery of $1 \mathrm{H}$-benzo[d][,2,3]triazol-1-yl 3,4,5-trimethoxybenzoate as a potentia antiproliferative agent by inhibiting histone deacetylase. Bioorg Med Chem 18: 8457-8462.

36. Zhang S, Luo Y, He LQ, Liu ZJ, Jiang AQ, et al. (2013) Synthesis, biologica evaluation, and molecular docking studies of novel 1,3,4-oxadiazole derivatives possessing benzotriazole moiety as FAK inhibitors with anticancer activity. Bioorg Med Chem 21: 3723-3729.

37. Lokhande TN, Viswanathan CL, Juvekar AS (2008) Synthesis and evaluation of novel N-substituted-6-methoxynaphthalene-2-carboxamides as potential chemosensitizing agents for cancer. Chem Pharm Bull (Tokyo) 56: 894-896.

38. Carta A, Briguglio I, Piras S, Boatto G, La Colla P, et al. (2011) 3-Aryl-2-[1Hbenzotriazol-1-yl]acrylonitriles: a novel class of potent tubulin inhibitors. Eur $\mathrm{J}$ Med Chem 46: 4151-4167.

39. Zhang SS, Zhang HQ, Li D, Sun LH, Ma CP, et al. (2008) A novel benzotriazole derivative inhibits proliferation of human hepatocarcinoma cells by increasing 
Citation: Ren Y, Zhang L, Zhou CH, Geng RX (2014) Recent Development of Benzotriazole-based Medicinal Drugs. Med chem 4: 640-662. doi:10.4172/2161-0444.1000207

oxidative stress concomitant mitochondrial damage. Eur J Pharmacol 584: 144-152.

40. Wan J, Yan X, Ma CP, Bi S, Zhu HL (2010) Synthesis, structure characterization, and biological evaluation of some new, 2,3-benzotriazole derivatives. Med Chem Res 19: 970-983.

41. Howell LA, Howman A, O'Connell MA, Mueller A, Searcey M (2009) Synthesis and evaluation of 9-aminoacridines derived from benzyne click chemistry. PubMed Bioorg Med Chem Lett 19: 5880-5883.

42. Guo H, Zhang GL, Zhang T, He XR, Wu ZY, et al. (2011) Synthesis, characterization and biological evaluation of some 16ß-azolyl-3ß-amino-5aandrostane derivatives as potential anticancer agents. Eur J Med Chem 46 3662-3674.

43. Zhou CH, Gan LL, Zhang YY, Zhang FF, Wang GZ, et al. (2009) Review on supermolecules as chemical drugs. Sci China Ser B-Chem 52: 415-458.

44. Zhou CH, Zhang YY, Yan CY, Wan K, Gan LL, et al. (2010) Recent researches in metal supramolecular complexes as anticancer agents. Anti-Cancer Agents Med Chem 10: 371-395.

45. Herchel R, Sindelar Z, Travnicek Z, Zboril R, Vanco J (2009) Novel 1D chain $\mathrm{Fe}(\mathrm{III})$-salen-like complexes involving anionic heterocyclic $\mathrm{N}$-donor ligands. Synthesis, X-ray structure, magnetic, (57) Fe Mossbauer, and biological activity studies. Dalton Trans 44: 9870-9880.

46. El-Asmy HA, Butler IS, Mouhri ZS, Jean-Claude BJ, Emmam MS, et al. (2014) Zinc(II), ruthenium(II), rhodium(III), palladium(II), silver(I), platinum(II) and $\mathrm{MoO} 22+$ complexes of 2-(2'-hydroxy-5'-methylphenyl)-benzotriazole as simple or primary ligand and 2,2'-bipyridyl, 9,10-phenanthroline or triphenylphosphine as secondary ligands: structure and anticancer activity. J Mol Struct 1059: 193 201.

47. Snegur LV, Nekrasov YS, Sergeeva NS, Zhilina ZV, Gumenyuk VV et al. (2008) Ferrocenylalkyl azoles: bioactivity, synthesis, structure. Appl Organometal Chem 22: 139-147.

48. Zhou CH, Luo Y (2008) Bistriazolone, bistriadimenol compounds with antimicrobial activity, and salts, synthesis method and uses thereof. CN Patent CN101323600.

49. Wang $Y$, Zhou CH (2011) Recent advances in the researches of triazole compounds as medicinal drugs. Scientia Sinica Chimica 41: 1429-1456.

50. Cui SF, Ren Y, Zhang SL, Peng XM, Damu GL, et al. (2013) Synthesis and biological evaluation of a class of quinolone triazoles as potential antimicrobial agents and their interactions with calf thymus DNA. Bioorg Med Chem Lett 23 : 3267-3272.

51. Zhou CH, Mi JL (2009) Preparation of Fluotrimazole ether derivatives as antimicrobial agents. CN Patent CN101391986 (A)

52. Zhou CH, Fang B, Gan LL (2008) Benzyl chloride tertiary amine double azole antimicrobial compounds, preparation and medical use thereof. CN Patent CN101323594 (B).

53. Kathiravan MK, Salake AB, Chothe AS, Dudhe PB, Watode RP, et al. (2012) The biology and chemistry of antifungal agents: a review. Bioorg Med Chem 20: $5678-5698$.

54. Jamkhandi CM, Disouza J (2013) Synthesis and antimicrobial evaluation of $1 \mathrm{H}$-benzotriazol -1-yl\{2-hydroxy-5-[(E) phenyldiazenyl] phenly\}methanone derivative. Int. J Pharm Pharm Sci 5: 225-228.

55. Sudhir MS, Nadh RV, Radhika S (2013) Antifungal activities of nove ,2,3-benzotriazole derivatives synthesized by ultrasonic and solvent-free conditions. Drug Invention Today 5: 126-132.

56. Wang XL, Wan K, Zhou CH (2010) Synthesis of novel sulfanilamide-derived ,2,3-triazoles and their evaluation for antibacterial and antifungal activities. Eur J Med Chem 45: 4631-4639.

57. Zhou $\mathrm{CH}$, Wei JJ Sugar-diaryl triazole compound with antimicrobial activity and synthesis and medical application thereof. CN Patent CN102086221 (A), June 8, 2011.

58. Zhou CH, Wu J, Jin L, Mi JL, Zhang FF, Jang $Y$ Triazoles compounds with antimicrobial activity and preparation method and pharmaceutical use thereof. CN Patent CN101445488 (A), June 3, 2009.

59. Zhou $\mathrm{CH}, \mathrm{Mi} \mathrm{JL}, \mathrm{Wu}$ J, Luo $\mathrm{Y}$, Bai $\mathrm{X}$, et al. Triazole onium compound with antimicrobial activity, preparation method and medical use. CN Patent CN101391985 (A), March 25, 2009.

60. Zhou $\mathrm{CH}$, Cui SF Carbostyril compounds and the preparation method and application. CN Patent CN102627630 (A), August 8, 2012.
61. Wang Y, Damu GL, Lv JS, Geng RX, Yang DC, et al. (2012) Design, synthesis and evaluation of clinafloxacin triazole hybrids as a new type of antibacterial and antifungal agents. Bioorg Med Chem Lett 22: 5363-5366.

62. Zhang HZ, Damu, GLV, Cai GX, Zhou CH (2014) Current developments in the syntheses of 1,2,4-triazole compounds. Curr Org Chem 18: 359-406.

63. Zhang YY, Mi JL, Zhou CH, Zhou XD (2011) Synthesis of novel fluconazoliums and their evaluation for antibacterial and antifungal activities. Eur J Med Chem 46: 4391-4402.

64. Zhang HZ, Damu GLV, Cai GX, Zhou CH (2013) Design synthesis and antimicrobial evaluation of novel benzimidazole type of fluconazole analogues and their synergistic effects with chloromycin, norfloxacin and fluconazole. Eur J Med Chem 64: 329-344.

65. Patel PD, Patel MR, Kocsis B, Kocsis E, Graham SM, et al. (2010) Design synthesis and determination of antifungal activity of 5(6)-substituted benzotriazoles. PubMed Eur J Med Chem 45: 2214-2222.

66. Wang QP, Zhang JQ, Damu GLV, Kun W, Zhang HZ, Zhou CH (2012) Synthesis and biological activities of thio-triazole derivatives as new potential antibacterial and antifungal agents. Sc. China Chem 55: 2134-2153.

67. Yu GP, Xu LZ, Yi X, Bi WZ, Zhu Q, et al. (2009) Synthesis and fungicidal evaluation of 2-arylphenyl ether-3-(1H-,2,4-triazol-1-yl)propan-2-ol derivatives. J Agric Food Chem 57: 4854-4860.

68. Wan K, Zhou CH (2010) Synthesis of novel halobenzyloxy and alkoxy 1,2,4-triazoles and evaluation for their antifungal and antibacterial activities. Bul. Korean Chem Soc 31: 2003-2010.

69. Rezaei Z, Khabnadideh S, Pakshir K, Hossaini Z, Amiri F, et al. (2009) Design, synthesis, and antifungal activity of triazole and benzotriazole derivatives. Eur J Med Chem 44: 3064-3067.

70. Gaber HM, Hafiz IS, M EK, Sherif SM (2010) New fused pyrimidines of potentia biosignificant interest. Syntheses and molecular modelling studies. Acta Chim Slov 57: 230-243.

71. Rauf A, Gangal S (2008) Facile one-pot synthesis of $\mathrm{N}$-acyl-1H-,2,3 benzotriazoles from internal and terminal olefinic fatty acids and their antimicrobial screening. J Oleo Sci 57: 453-457.

72. Rezaei Z, Khabnadideh S, Zomorodian K, Pakshir K, Kashi G, et al. (2011) Design, synthesis and antifungal activity of some new imidazole and triazole derivatives. Arch Pharm (Weinheim) 344: 658-665

73. Khabnadideh S, Rezaei Z, Pakshir K, Zomorodian K, Ghafari N (2012) Synthesis and antifungal activity of benzimidazole, benzotriazole and aminothiazole derivatives. Res Pharm Sci 7: 65-72.

74. Saad R, Zemity E (2011) Antimicrobial activity of some 2-amino-5-subsituted pyridine derivatives. Arch Phytopathology Plant Protect 44:381-389.

75. Saini R, Chaturvedi S, Kesari AN, Kushwaha S (2010) Synthesis of 2-(substituted)-5- (benzotriazomethyl)-1,3,4-oxadiazole for anti-fungal activity. Der Pharma Chemica 2: 297-302.

76. Zhou $\mathrm{CH}$, Zhang $\mathrm{HZ}$ Preparation of benzimidazolamine derivatives as antibacterial and/or antifungal agents. CN Patent CN102659687 (A), September 12, 2012

77. Zhang HZ, Lin JM, Rasheed S, Zhou CH (2014) Design, synthesis and biological evaluation of novel benzimidazole derivatives and their interaction with calf thymus DNA and synergistic effects with clinical drugs. Sci China Chem 57: 807-822.

78. Singh RJ (2009) Syntheses of some new 1,2,3-benzotriazoles as antimicrobia agents. Rasayan J Chem 2: 598-601.

79. Lv JS, Peng XM, Babu BK, Zhou CH (2014) 1,2,3-Triazole-derived naphthalimides as a novel type of potential antimicrobial agents: synthesis antimicrobial activity, interaction with calf thymus DNA and human serum albumin. Bioorg Med Chem Lett 24:308-313.

80. Zhang YY, Zhou CH (2011) Synthesis and activities of naphthalimide azoles as a new type of antibacterial and antifungal agents. Bioorg Med Chem Lett 21: $4349-4352$.

81. Toraskar MP, Kadam VJ, Kulkarni VM (2009) Synthesis and antifungal activity of some azetidinones. Int J Chem Tech Res 1194-1199.

82. Suma BV, Nathesh NN, Venkataramana CHS, Judy J, Madhawan V Synthesis and antibacterial of some new 1,2,3 benzotriazoles derivatives containing pyrazolidinedione moieties. Int J Pharm Pharm Sci 4:169-173.

83. Gaikwad ND, Patil SV, Bobade VD (2012) Synthesis and biological evaluation 
Citation: Ren Y, Zhang L, Zhou CH, Geng RX (2014) Recent Development of Benzotriazole-based Medicinal Drugs. Med chem 4: 640-662. doi:10.4172/2161-0444.1000207

of some novel thiazole substituted benzotriazole derivatives. Bioorg Med Chem Lett 22: 3449-3454

84. Bapna M, Parashar B, Sharma VK, Chouhan LS (2012) Microwave-assisted synthesis of some novel and potent antibacterial and antifungal compounds with biological screening. Med Chem Res 21:1098-1106.

85. Patel JS, Garg CS, Sen DJ (2012) Synthesis of novel N-substituted 2 - $(1 \mathrm{H}$-benzotriazol-1-yl)- acetohydrazide derivatives as antimicrobial agents. Int J Drug Dev \& Res 4: 322-329.

86. Han XL, An CX, Zhang ZH (2008) Two novel Ag(I) coordination polymers with triazoles derivatives: synthesis, crystal structures and biological activity. Appl Organometal Chem 22: 565-572.

87. An CX, Han XL, Wang PB, Zhang ZH, Zhang HK, et al. (2008) Synthesis, crystal structures, and biological activities of silver(I) and cobalt(II) complexes with an azole derivative ligand. Transition Met Chem 33: 835-841.

88. Patel PK, Patel PD (2010) Synthesis, characterization, metal complexation studies and biological screening of some newly synthesized metal complexes of 1-(4-carboxy-3-hydroxy-N-isopropyl phenyl amino methyl) benzotriazole with some transition metals. Int J Chem Tech Res 2: 1147-1152.

89. Khan SA, Kumar P, Joshi R, Iqbal PF, Saleem K (2008) Synthesis and in vitro antibacterial activity of new steroidal thiosemicarbazone derivatives. Eur J Med Chem 43: 2029-2034

90. Jose B, Reddy LJ (2010) Evaluation of antibacterial activity of the leaf and flower essential oils of gliricidia sepium from South India. Int J Appl Pharm 2: $20-22$

91. Zhou $\mathrm{CH}$, Fang B Medical application of halobenzyl tertiary amine type dibromo antimicrobial compound. CN Patent CN102140066 (A), August 3, 2011.

92. Zhou CH, Zhang WT Bioactive diaryl tert-amino-azole derivatives and their preparation, pharmaceutical compositions and use in the treatment of diseases. CN Patent CN102060793 (A), May 18, 2011.

93. Damu GLV, Wang QP, Zhang HZ, Zhang, YY Lv, JS Zhou, CH (2013) A series of naphthalimide triazoles: design, synthesis and bioactive evaluation as potential antimicrobial agents. Sci China Chem 56: 952-969.

94. Fang B, Zhou CH, Rao XC (2010) Synthesis and biological activities of nove amine-derived bis-azoles as potential antibacterial and antifungal agents. Eur J Med Chem 45: 4388-4398.

95. Saour KY, Atto RA (2012) Synthesis of new levofloxacin derivatives and their biological activity. Int J Comprehensive Pharma 3: 1-5.

96. Zhang SL, Chang JJ, Damu GLV, Fang B, Zhou, XD, et al. (2013) Novel berberine triazoles: Synthesis, antimicrobial evaluation and competitive interactions with metal ions to Human Serum Albumin. Bioorg Med Chem Let 23: $1008-1012$

97. Zhang L, Chang JJ, Zhang SL, Damu GLV, Geng, RX (2013) Synthesis and bioactive evaluation of novel hybrids of metronidazole and berberine as new type of antimicrobial agents and their transportation behavior by Human Serum Albumin. Bioorg Med Chem 21: 4158-4169.

98. Zhou CH, Chang JJ, Zhang YY (2012) Method for preparation of berberineazole derivative and application as antibacterial and antifungal agents. CN Patent CN102516242 (A), June 27.

99. Zhang SL Chang JJ, Damu GLV, Geng RX, Zhou CH (2013) Berberine azoles as antimicrobial agents: synthesis, biological evaluation and their binding profile investigation with Human Serum Albumin. Med Chem Comm 4:839-846.

100. Huczynski A, Janczak, J, Antoszczak M , Stefanska J, Brzezinski B (2012) X-ray, FT-IR, NMR and PM5 structural studies and antibacterial activity of unexpectedly stable salinomycin-benzotriazole intermediate ester. J Mol Struct 1022:197-203.

101. Shi Y, Zhou CH (2011) Synthesis and evaluation of a class of new coumarin triazole derivatives as potential antimicrobial agents. Bioorg Med Chem Lett 21: $956-960$.

102.Peng XM, Damu GL, Zhou C (2013) Current developments of coumarin compounds in medicinal chemistry. Curr Pharm Des 19: 3884-3930.

103.Damu GL, Cui SF, Peng XM, Wen QM, Cai GX, et al. (2014) Synthesis and bioactive evaluation of a novel series of coumarinazoles. Bioorg Med Chem Lett 24: 3605-3608.

104.Damu GLV, Wen QM, Cui SF, Peng, XM, Zhou CH Coumarin-based triazole compounds with preparation method and pharmaceutical use thereof. $\mathrm{CN}$ Patent CN102796085 (A), December 28, 2012.
105.Damu GLV, Wen QM, Cui SF, Li QX ,Peng XM, Zhou CH Coumarin-based triazole alcohols with preparation method and pharmaceutical use thereof. $\mathrm{CN}$ Patent CN102796087 (A), December 28, 2012.

106. Shi Y, Zhou CH, Zhou XD, Geng RX, Ji QG (2011) [Synthesis and antimicrobial evaluation of coumarin-based benzotriazoles and their synergistic effects with chloromycin and fluconazole]. Yao Xue Xue Bao 46: 798-810.

107.Zhou $\mathrm{CH}$, Shi Y, Wan K Coumarin azole compound with antimicrobial activity, and preparation method and medicinal application thereof. CN Patent. CN 102040592 (A), May 4, 2011.

108. Nowakowska Z, Kedzia B, Schroeder G (2008) Synthesis, physicochemical properties and antimicrobial evaluation of new $(E)$-chalcones. Eur $\mathrm{J}$ Med Chem 43: 707-713.

109. Visagaperumal D, Praveen V, Sudeepthi P, Prasanthi P, Sravani GG Satyanarayana G (2010) Synthesis and antimicrobial evaluation for certain 1-(1H-benzotriazol-1-yl)-1-substituted phenylmethanamine. Int J Chem Sci 8 : $1315-1320$.

110. Dubey A, Srivastava SK, Srivastava SD (2011) Conventional and microwave assisted synthesis of 4-oxo-2-substituted aryl-,3-thiazolidine derivatives of benzotriazole: a new class of biological compounds. Analele UniversitaNii din Bucuresti-Chimie serie noua 20: 115-121.

111. Wan J, Lv PC, Tian NN, Zhu HL (2010) Facile synthesis of novel benzotriazole derivatives and their antibacterial activities. J Chem Sci 122: 597-606.

112. Ningegowda R, Kavitha CV, Priya, BS, Gaonkar SL, Tejesvi MV (2009) Microwave-assisted solvent-free synthesis of $\mathrm{N}$-alkyl benzotriazole derivatives: Antimicrobial Studies. Lett Drug Des Discov 6: 502-507.

113. Narinder PS, Rajesh K, Deo NP, Sarita, S, Om S (2011) Synthesis and antibacterial activity of benzotriazole substituted acridines. Int $\mathrm{J}$ Biol Chem 5:193-199.

114. Purvesh JS, Hasmukh SP, Bhupendra PP (2013) Synthesis, characterization and antimicrobial activity of novel sulphapiperazine containing arylazopyrazoles. J Saudi Chem Society 17: 307-313.

115. Sarmah KN, Sarmah NK, Kurmi KB, Patel TV (2012) Syntheses \& studies of biological evaluation of certain s-triazine derived compounds. Int $\mathrm{J}$ Chem Tech Res 4: 677-681.

116. Pochampalli J, Mandala D, Umapathireddy N, Rajakomuraiah $P$ An efficient synthesis, characterization and antimicrobial screening of $\mathrm{N}$-substituted 2-(piperidin-4-yl)-2H-benzo[d] [2, 3] triazoles. Lett Drug Des Discov (2012) 9 : 471-478.

117. Ramachandran R, Rani M, Senthan S, Jeong YT, Kabilan S (2011) Synthesis, spectral, crystal structure and in vitro antimicrobial evaluation of imidazole/ benzotriazole substituted piperidin-4-one derivatives. Eur J Med Chem 46:1926-1934.

118. Patel BP, Patel HS, Shah PJ (2010) Synthesis and antibacterial activity of some new azopyrazoles. Bulg Chem Commun 42: 274-278.

119. Shukla SN, Gaur P, Kaur H, Srivastava RS Synthesis, spectroscopic characterization and antibacterial activity of some chloro dimethylsulphoxide/ tetramethylenesulphoxide ruthenium (II)/(III)complexes with ,2,3-benzotriazole. Acta Chim Slov (2011) 58: 542-548.

120. Parekh DV, Desai PS Synthesis, characterization and antimicrobial activity studies of 5-(2-(5-benzoyl- 1H-,2,3-benzotriazole-1-yl) 2-oxoethylamino)-2hydroxybenzoic acid and their transition metal chelates. Adv Appl Sci Res (2012) 3: 1992-1996.

121. Augustynowicz-KopeÄ E, Zwolska Z, Orzeszko A, Kazimierczuk Z (2008) Synthesis and antimycobacterial activity of selected nitrobenzyloxylated benzotriazoles. Acta Pol Pharm 65: 435-439.

122. Ramalingam P, Ganapaty S, Rao ChB (2010) In vitro antitubercular and antimicrobial activities of 1 -substituted quinoxaline-2,3(1H,4H)-diones. Bioorg Med Chem Lett 20: 406-408.

123. Dubey A, Srivastava SK, Srivastava SD (2011) Conventional and microwave assisted synthesis of 2-oxo-4-substituted aryl-azetidine derivatives of benzotriazole: a new class of biological compounds. Bioorg Med Chem Let 21: 569-573.

124. Sharma R, Samadhiya P, Srivastava SD, Srivastava SK (2011) Synthesis and Biological Activity of New Series of N-[3-(1H-,2,3-Benzotriazol-1-yl)propyl]2-(substituted Phenyl)-3-Chloro-4-Oxo-1-Azetidinecarboxamide. Acta Chim Slov 58: 110-119.

125. Tasneem T, Shraddha VR, Ravindra RK (2014) Synthetic utility of sydnones 
Citation: Ren Y, Zhang L, Zhou CH, Geng RX (2014) Recent Development of Benzotriazole-based Medicinal Drugs. Med chem 4: 640-662. doi:10.4172/2161-0444.1000207

to couple pharmacologically important heterocycles for antitubercular activity. Arab J Chem DOI 10.1016/j.arabjc.2011.01.029 (in press).

126. Taj T, Kamble RR, Gireesh TM, Hunnur RK (2011) Facile syntheses of Mannich bases of 3-[p-(5- arylpyrazolin-3-yl)phenyl]sydnones, as anti-tubercular and anti-microbial agents, under ionic liquid/tetrabutylammonium bromide catalytic conditions. J Serb.Chem Soc 76: 1069-1079.

127. Kumar V, Malhotra SV (2008) Synthesis of nucleoside-based antiviral drugs in ionic liquids. Bioorg Med Chem Lett 18: 5640-5642.

128. Kang IJ, Wang LW, Yeh TK, Lee CC, Lee YC, et al. (2010) Synthesis, activity, and pharmacokinetic properties of a series of conformationally-restricted thiourea analogs as novel hepatitis $C$ virus inhibitors. Bioorg Med Chem 18 : 6414-6421.

129. Tonelli M, Paglietti G, Boido V, Sparatore F, Marongiu F, et al. (2008) Antivira activity of benzimidazole derivatives. I. Antiviral activity of 1-substituted-2 [(benzotriazol-1/2-yl)methyl]benzimidazoles. Chem Biodivers 5: 2386-2401.

130.Guo RH, Zhang Q, Ma YB, Huang XY, Luo J, et al. (2011) Synthesis and biological assay of 4-aryl-6-chloro-quinoline derivatives as novel nonnucleoside anti-HBV agents. Bioorg Med Chem 19: 1400-1408.

131. Gopi H, Umashankara M, Pirrone V, LaLonde J, Madani N, et al. (2008) Structural determinants for affinity enhancement of a dual antagonist peptide entry inhibitor of human immunodeficiency virus type-1. J Med Chem 51 2638-2647.

132. Sakthi S, Periyasamy S, Sampath K, Clercq ED (2010) Synthesis, anti-vira and cytotoxicity studies of some 2-phenyl-3-substituted quinazolin-4-(3H)ones. Int J.Pharmacy and Pharm 2: 71-79.

133. Weng ZY, Wei W, Dong XW, Hu YZ, Huang SF (2011) Synthesis and biological evaluation of novel piperidin-4-ol derivatives. Monatsh Chem 143: 303-308.

134.Sudhir MS, Nadh, RV (2013) Evaluation of in vitro anthelmintic activities of novel 1,2,3-benzotriazole derivatives synthesized in ultrasonic and solvent free conditions. J Pharm Res 7: 47-52.

135. Nag S, Prasad K, Bhowmick A, Deshmukh R, Trivedi V (2013) PfRIO-2 kinase is a potential therapeutic target of antimalarial protein kinase inhibitors. Curr Drug Discov Technol 10: 85-91.

136. Lopez-Vallejo F1, Castillo R, Yepez-Mulia L, Medina-Franco JL (2011) Benzotriazoles and indazoles are scaffolds with biological activity against Entamoeba histolytica. J Biomol Screen 16: 862-868.

137. Becerra MC, Guinazu N, Hergert LY, Pellegrini A, Mazzieri MR, et al. (2012) In vitro activity of $\mathrm{N}$-benzenesulfonylbenzotriazole on Trypanosoma cruzi epimastigote and trypomastigote forms. Exp Parasitol 131: 57-62.

138. Yin BT, Yan CY, Peng XM, Zhang SL, Rasheed S, et al. (2014) Synthesis and biological evaluation of Ît-triazolyl chalcones as a new type of potential antimicrobial agents and their interaction with calf thymus DNA and human serum albumin. Eur J Med Chem 71: 148-159.

139. Jin L, Yan CY, Gan LL, Zhou, CH (2010) New progress in study on biological activities of chalcones. Chin J Biochem Pharm 3: 358-361.

140.Zhou CH, Yan CY 2'-Aminochalcone, pyrazoline, cyclopropylazole derivatives and their preparation, pharmaceutical compositions and use in the treatment of diseases. CN Patent CN102060792 (A), May 18, 2011.
141. Awasthi SK, Mishra N, Dixit SK, Singh A, Yadav M, et al. (2009) Antifilarial activity of ,3-diarylpropen-1-one: effect on glutathione-S-transferase, a phase II detoxification enzyme. Am J Trop Med Hyg 80: 764-768.

142. Mishra N, Arora P, Kumar B, Mishra LC, Bhattacharya A, et al. (2008) Synthesis of novel substituted ,3-diaryl propenone derivatives and their antimalarial activity in vitro. Eur J Med Chem 43: 1530-1535.

143. Jamkhandi CM, Disouza JI (2013) Evaluation of antioxidant activity for some benzotriazole substituted with $\mathrm{N}$-phenylacetamide and acetylcarbamic acid derivatives. Int J Pharm Pharm Sci 5: 249-253.

144. Simunovic M, Perkovic I, Zorc B, Ester K, Kralj M, et al. (2009) Urea and carbamate derivatives of primaquine: synthesis, cytostatic and antioxidant activities. Bioorg Med Chem 17: 5605-5613.

145. Perkovic I, Butula I, Kralj M, MartinKleiner I, Balzarini J (2012) Novel NSAID 1-acyl-4-cycloalkyl/arylsemicarbazides and 1-acyl-5-benzyloxy/hydroxy carbamoylcarbazides as potential anticancer agents and antioxidants. Eur $J$ Med Chem 51: 227-238.

146. Rajic Z, Hadjipavlou-Litina, Pontiki D, Balzarini E, J Zorc (2011) The nove amidocarbamate derivatives of ketoprofen: synthesis and biological activity. Med Chem Res 20: 210-219.

147. Jain NP, Upasani CD, Kalkotwar RS, Jain UN (2013) Synthesis and antiinflammatory activity of $\mathrm{N}$-(alkyl or aryl)-2-(1 H-benzotriazol-1-yl) acetamide derivatives. Res J Pharm Biol Chem Sci 4: 1470-1480.

148. Bovens S, Kaptur M, Schulze-Elfringhoff A, Lehr M (2009) 1-(5-carboxyindol1-yl) propan-2-ones as inhibitors of human cytosolic phospholipase A2a: synthesis and properties of bioisosteric benzimidazole, benzotriazole and indazole analogues. Bioorg Med Chem Lett 19: 2107-2111.

149. Wang XL, Gan LL, Yan CC, Zhou CH Synthesis of diphenyl piperazine sulfanilamides and evaluations of their antimicrobial activities. Scientia Sinica Chimica 20: 451-460.

150. Dai LL, Cui SF, Damu GLV, Zhou CH (2013) Synthesis and advance in research of tetrazoles. Chin J Org Chem 33: 224-244.

151. Rajasekaran A, Rajagopal KA (2009) Synthesis of some novel triazole derivatives as anti-nociceptive and anti-inflammatory agents. Acta Pharm 59: 355-364.

152.Palmer WS, Alam M, Arzeno HB, Chang KC, Dunn JP, et al. (2013) Development of amino-pyrimidine inhibitors of c-Jun N-terminal kinase (JNK) kinase profiling guided optimization of a ,2,3-benzotriazole lead. Bioorg Med Chem Lett 23: 1486-1492.

153.Patel D, Jain M, Shah SR, Bahekar R, Jadav P, et al. (2011) Discovery of orally active, potent, and selective benzotriazole-based PTP1B inhibitors. ChemMedChem 6: 1011-1016.

154. De Moor O, Dorgan CR, Johnson PD, Lambert AG, Lecci C, et al. (2011) Discovery and SAR of 2-arylbenzotriazoles and 2-arylindazoles as potential treatments for Duchenne muscular dystrophy. Bioorg Med Chem Lett 21: 4828-4831.

155. Kumar P, Tripathi L (2012) A new class of anticonvulsants possessing $6 \mathrm{~Hz}$ psychomotor seizure test activity: 2-(1H-benzotriazol-1-yl)-N'-[substituted] acetohydrazides. Med Chem 8: 337-348. 